\title{
Post-Pandemi Süreci İçin Ekonomik Kalkınma Arayışı: Türkiye Örneği
}

\author{
İlkay Güler* \\ Ankara Hacı Bayram Veli Üniversitesi
}

\section{Öz}

Ekonomik kalkınma modellerinden; Hirschman'ın dengesiz kalkınma modelinde, diğerleri ile ilişkileri fazla olan sektörler önem taşırken ihracata dayalı sanayileşme modelinde üretimi ithalata bağımlılığı düşük olan sektörler değer görmekte, sürdürülebilir kalkınma için ise ekonomik kalkınmanın yanında çevrenin korunması hedeflenmektedir. COVID-19 salgını nedeniyle kırılan küresel ticaret zinciri bizi genel geçer tek bir gerçeklik olmadığı olgusu ile yüzleştirmektedir. Çalışmada, post-pandemi sürecinde, ekonomik kalkınmanın gerçekleșebilmesi hangi kalkınma modelinin uygulanması gerektiğini belirlemek için, Giddens'ın kavşak oluşturma çabası temel alınmıș, WIOD tarafından en son yayımlanan veriler kullanılmıştır. Bu bağlamda; Hirschman'ın ve Rasmussen'in anahtar sektörleri, ithalata bağımlılığı en düşük olandan en yüksek olana doğru sıralanmakta, üretim zincirinin Leontief benzerlik analizi ve Mann Whitney-U testi ile dönemler arasındaki benzerlikler belirginleştirilmiştir, bir birim çevre ve enerji kullanım emisyonları ile eşleştirilmektedir. Post-pandemi sürecinde, Türkiye'de ekonomik kalkınma için oluşturulacak kavşakta toplanacak sektörler aynı zamanda ekonomik kalkınmanın anahtarı olacaktır. Söz konusu sektörler; tekstil, giyim eșyası ve deri ürünleri imalatı, kâğıt ve kâğıt ürünleri imalatı, kimyasal madde ve ürünlerin imalatı, bilgisayar, elektronik ve optik ürünlerin imalatı sektörler olarak tespit edilmiştir.

\section{Anahtar Kelimeler}

anahtar sektör, ekonomik kalkınma, post-pandemi, sürdürülebilir kalkınma

* Öğr. Gör. Dr., Ankara Hacı Bayram Veli Üniversitesi, Tapu Kadastro Yüksekokulu, Emlak ve 


\title{
Seeking Economic Development for The Post-Pandemic Period: The Case of Turkey
}

\begin{abstract}
In the Unbalanced Growth Theory of Hirschman, which is one of the economic development models, while the sectors with high inter-sectoral relations are important, the sectors in which dependence of production on imports is low are valued in the export-based industrialization model, and in addition to economic development, environmental protection is targeted for sustainable development. The global trade chain that has been broken due to the COVID-19 confronts us with the fact that there is no single reality. The study is based on Giddens effort to create a crossroad to determine which model should be applied to achieve economic development in the post-pandemic period. In this context; by making Input-output analysis, coefficients of total forward linkages, import dependency coefficients of the sectors' production and environmental-energy emission coefficients per unit are calculated. The data the most recently published by WIOD was used. Through the obtained coefficients, the key sectors of Hirschman and Rasmussen are determined, the key sectors are ranked from the sector with the lowest dependence on imports to the sector with the highest and are matched, the similarity of the production chain between periods with the Leontief similarity analysis and Mann Whitney-U test are determined with environmental-energy use emissions per unit. In the post-pandemic period, the sectors in crossroad which will be created for economic development in Turkey will also be the key to economic development. These sectors; manufacture of textiles, wearing apparel and leather products, manufacture of paper and paper products, manufacture of chemicals and chemical products, manufacture of computer and electronic and optical products.
\end{abstract}

\section{Keywords}

key sector, economic development, post-pandemic, sustainable development

\section{Extended Abstract}

\section{Introduction}

Broken global trade link because of COVID-19 pandemic, confronting us with the fact that there is no just one universal consent reality, showed there cannot be a unique model of economic development. Unbalanced development model or export-oriented industrialization model or sustainable development has been seen impossible standing alone. At this point, Giddens'effort to build crossroads springs to mind for the economic development to realize. When developmental models are evaluated, instead of applying just one model, it has been aimed to identify sectors with high inter-sectoral linkages, which are low export-oriented, whose interperiod production chain showing similarities, whose environment and energy usage emission is low or whose potential to reduce emission with the help of policies is high in this study. 


\section{Methodology}

The main objective of this study is to determine the strategical sectors to invest in post COVID-19 pandemic. In our present conditions in which the use of one single economic model is not enough for economic development, it has been targeted to build up a crossroads through the obtained results accounting all development parameters which have potentiality to be assessed through input-output analysis separately, one by one. To determine the priority sectors for investment; although studies take place to regulate key sectors, accumulating whole development indicators in one crossroads has not been coincided yet in literature, in this framework, making up a new development model expresses the importance of the research.

In this study, five different analyses have been made on the basis of input-output analysis. The analysis while being used to predict the economic activities in future, within the scope of assessed coefficients, reliability of predicts depends on the reliability of structural coefficients and the final demand. In this context, domestic input-output table and import input-output table of Turkey released by WIOD and the most up-to-date data including satellite accounts for environment and energy use have been used. The first analysis is to calculate Hirschman key sectors. Manufacture of chemicals and chemical products sector that provides us with the production of disinfectant in the fight against COVID-19, manufacture of basic metals, manufacture of computer, electronic and optical products sectors that make it possible to produce respiratory devices, manufacture of paper and paper products sectors that realize the production of disposable materials for hospitals such as bed sheet, towel, etc. to be thrown away after use are the sectors taking place in Hirschman's category of key sectors.

The second analysis is to assess Rasmussen key sectors. Sectors which are our proud in the struggle against pandemic take place in sectors that are assessed according to Rasmussen criteria. The leading sector in these sectors is manufacture of textiles, wearing apparel and leather products sector in which mask and clothing are manufactured to protect the medical staff, and Manufacture of chemicals and chemical products sector that helps us with the production of disinfectant taking place in Hirschman's category of key sectors, Manufacture of basic metals, manufacture of computer, electronic and optical products sectors which supply the production of respiratory devices, manufacture of paper and paper products sectors that realize the manufacturing of disposable materials for hospitals like bed sheet, towel, etc. to be thrown away after using once. Other sectors that take place in this category can be counted as manufacture of coke and refined petroleum products, Electricity, gas, steam and air conditioning supply sectors.

The third analysis is to assess the import dependency of production. As the result of the analysis, all of the sectors mentioned in manufacturing have a high import dependency along with the globalization. 
Sectors which have potential to take place at the economic crossroads are Supply of electricity, gas, steam and air-conditioning, manufacture of textiles, wearing apparel and leather products, manufacture of chemicals and chemical products, manufacture of paper and paper products, and which have potential to take place at the developmental crossroads are manufacture of paper and paper products, manufacture of coke and refined petroleum products, manufacture of chemicals and chemical products, manufacture of computer, electronic and optical products, manufacture of basic metals sectors. As a result of the analysis to analyze the sectors which these sectors use the most imported inputs have been seen to be mostly their own sectors.

The fourth analysis is Leontief similarity analysis and Mann Whitney-U test to determine if inter-period chain of production of sectors which have a high potential to take place at the crossroads, we have constructed shows similarity or not. These analyses having the feature of indicating if there is a structural change or not in production, they are of great importance for our economic development crossroads. According to the test results, statistically there exists no meaningful difference among the medians of production chains of sectors which have the potential of economic development and therefore the conclusion has been reached that input components which are supplied for production have not become different.

The fifth analysis is to calculate energy use and $\mathrm{CO}_{2}$ emissions created by one single unit. Determining $\mathrm{CO}_{2}$ emissions released by sectors as a result of one single unit production and the emissions of energy use is of utmost importance. Through this assessment, the rate of sectors'polluting the environment is specified, the current situation is determined and if the rate being talked about is too much, the required policy and precautions have been suggested. In the analysis, the most current data including the satellite accounts for the environment and energy use emissions in WIOD database has been used. In Turkey, sectors which have a high potential to take part at the crossroads constructed for economic development spreading $\mathrm{CO}_{2}$ to the environment as a result of one single unit production and having the highest coefficient of energy use emission are sectors such as Electricity, gas, steam and air conditioning supply, Manufacture of coke and refined petroleum products and Manufacture of basic metals. While increasing the production of these sectors supplies the economic development, it will cause a high amount of environment pollution on the other hand. Hence, sectors being mentioned here should continue their present production not taking place at the economic development crossroads. Yet, as the emission will be high even in such a case, global targets stated in the 11th Development Plan and United Nations Development Program determined for the sustainable development should necessarily be applied.

\section{Findings}

Results obtained from 5 analyses we have applied provide us with building crossroads for the economic development. Sectors like manufacture of tex- 
tiles, wearing apparel and leather products, Manufacture of paper and paper products, manufacture of chemicals and chemical products, and manufacture of computer, electronic and optical products take place at the economic development crossroads made for the post-pandemic period.

\section{Conclusion}

In the research, a new development model has been suggested being inspired by Giddens' crossroads approach constructed between positivism and hermeneutik view with the aim of determining in which sectors to increase production during post-pandemic period. Analysis applied is based on input-output analysis and data used helps only with determining the state. Within this scope, economic development crossroad we have built just takes the photo of the present and lights the way for the economic development during post-pandemic period.

Sectors taking place at the economic development crossroads we have built are at the same time the sectors that produce mask, medical protective clothing, disinfectant; disposable materials for hospitals such as bed sheet, towel, etc. to be thrown away after use in the fight with COVID-19 pandemic and sectors constituting the cornerstone of manufacturing respiratory devices. To prevent the sustainable development from causing an unsustainable environment, it is of utmost importance to put environmental policies recommended in the study into practice. Electricity, gas, steam and air conditioning supply sectors as the leading sectors and manufacture of coke and refined petroleum products sectors and main metal manufacturing sectors can also take place at the economic development crossroads providing that $\mathrm{CO}_{2}$ and energy use emissions are reduced. It is required that sectors recommended to take place at the economic development crossroads should be made free of imported-input dependency urgently and our production should be realized with domestic and national opportunities. As a result of the realization of all these conditions, sectors which will collect around the crossroads to be constructed for the economic development during post-pandemic period will be the key to the economic development at the same time. Sectors to mention here are manufacture of textiles, wearing apparel and leather products, manufacture of paper and paper products, Manufacture of chemicals and chemical products, and Manufacture of computer, electronic and optical products.

During post-pandemic period, to make sure that the wheels are turning, these precautions should be taken: to help increase the production of sectors that are at the crossroads we constructed, supports should be supplied; economic incentives should be provided; in case there occurs production surplus, the state should be the final purchaser, the rates of value added tax and special consumption tax should be reduced to boost the demand. Domestic intermediate input production should be focused not to encounter again with imported-input problem occuring after breaking of supply chain in the COVID-19 pandemic. 


\section{Giriş}

Çin'de başlayan COVID-19 salgını bir taraftan insan sağlığını tehdit ederken diğer taraftan ekonomiyi olumsuz etkilemektedir. Pandemiyi kontrol altına almak için izolasyon merkezli alınan önlemlerin başında; sokağa çıkma kısıtlamaları, büyükşehirlere giriş-çıkışların engellenmesi, hava trafiğinin durmasl, alışveriş merkezleri ve semt pazarları gibi son tüketicinin temel tüketim mallarına ulaştığı yaygın tedarik merkezlerinin önce kapatılması daha sonra kontrollü ve kısıtlı şekilde hizmete açılması sonucu toplam talep daralmış, bu daralma arzı da olumsuz etkilemiştir.

2020 yılının ilk üç ayında Çin ekonomisi neredeyse durma noktasına gelmiş ve küresel tedarik zincirinde aksamalar meydana gelmiştir. COVID-19 virüsünün Dünyadanın en büyük ekonomilerinde hızla etkin bir șekilde yaygınlaşması küre çapında ekonominin yavaşlamasına neden olmuştur. COVID-19 salgınıyla mücadele eden tüm ülkelerin, bu süreçte sosyal, siyasi ve iktisadi olarak güçlü ve zayıf yönleri belirginleşmiştir. Türkiye'nin ilk gözlemde dikkat çeken güçlü yanları; gıda konusunda yeterli stoğun bulunması, adaptif bir imalat sektörüne sahip olması, pandemiyle mücadelede talebi hızla artan maske, dezenfektan, solunum cihazları, koruyucu sağlık ekipmanları vb. ürünlerin arzını vakit kaybetmeden arttırabilmesi olarak sıralanabilir.

Salgın tüm etkileriyle değerlendirildiğinde sadece bir sağlık sorunu olarak kalmadığı, çok yönlü, yerel ve kürsel sorunlara kapı aralıdı̆̆ı söylenebilir. Bu sorunların başında ekonomik olanları öncelikli gündem olarak karşımıza çıkmaktadır. Bu yönüyle COVID-19 sadece Tıp tarihi kitaplarında aynı zamanda iktisat tarihi kitaplarında yer alması muhtemel bir olgudur. Arz ya da talep yönlü ekonomik krizlere aşina olan dünya ekonomileri pek az çift yönlü (arz ve talep) bir daralmayla başa çıkmak zorunda kalmıştır. COVID-19 pandemisinin etkileri üzerinden ulusal ve küresel bakış açısından birçok tahmin yapılmakta, bu tahminler arasında küresel bir sistem değiş̧imini öngörenler olduğu gibi aynı zamanda mevcut sistemin kan tazeleyerek dünyayı domine etmeye devam edeceğini iddia edenler de olmuştur. Yapılan yorumlar arasında yaşanan bu sürecin I. ve II. Dünya Savaşları ya da Soğuk Savaş sonrası dönemde yaşandığı gibi küresel ölçekte sistemde majör bir etkisi alamayacağı, 11 Eylül saldırıları, 2008 küresel finansal krizi gibi yeni üretim modellerine geçiş sağlayacağı görüşü reel politik dinamikler içinde makul görünmektedir. 1918-1920 yılları arasında tüm dünyayı etkisi altına alan İspanyol Gribi pandemisi şartlarında milli mücadelesini sürdüren Türkiyenin, içinde bulun- 
duğumuz zor koşulları da doğru stratejiler uygulandığında en az hasarla atlatacak potanisyele sahip olduğunu ifade etmek yanlış olmaycaktır.

Bu çalışmada, doğru stratejilerin belirlenmesine katkı sunmak amacıyla öncelikli sektörler tespit edilmeye ve bugüne kadar ayrı ayrı uygulanan kalkınma modelleri bir araya getirilerek bir kalkınma kavşağı oluşturulmaya çalışılmıştır. Çalışmanın birinci bölümünde, Giddens özelinde, COVID-19 pandemisi sonrası beklenen bölgesel ve küresel değişim ortamında bir kalkınma firsatı arayışı yer almaktadır. İkinci bölümde teorik çerçeve ve literatür bir arada değerlendirilmekte, üçüncü bölümde analizin amacl, önemi, verileri, tekniği ve uygulaması yer almakta, dördüncü bölümde ise analiz sonuçları çerçevesinde kalkınmada kavşak oluşturacak sektörler değerlendirilmekte ve son bölümde genel değerlendirme, sonuç ve öneriler yer almaktadır.

\section{Türkiye'de Post-Pandemi Sürecinde Ekonomik Kalkınma Çabası}

COVID-19 salgını ile emeğin, mal ve hizmetlerin, sermayenin serbestçe hareket ettiği bir dünyadan, sınırların kapatıldı̆̆ı, ulaşım imkânlarının kısıtlandığı, evden dişarıya çıkmanın dahi belirli kurallara tabi olduğu bir dünyaya hızla geçilmesi küreselleşme ve kendine yetebilirlik tartışmalarını yeniden akademik gündeme taşıdı. Ülkelerin kendi kendine yetebilmesinin önemi, özellikle stratejik sektörlerin korunmasının gerekliliği yürütülen tartışmaların merkezini oluşturmaktadır. Süreç içerisinde ABD ve Avrupa Birliğinde yaşanan gelişmeler yenidünyanın sonu söylemlerini de beraberinde getirdi. Bu süreçte işsizlik ve kısmî çalışma ödeneği gibi otomatik stabilizatörleri etkin kullanan, pahasa hafif olsa da süreçle mütenasip sembolik anlamı yüksek olan maske, sağlık çalışanları için koruyucu kıyafet ve ekipmanları ve yerli üretim solunum cihazlarından oluşan hibesini 57 ülkeye ulaştıran Türkiye, potansiyelini gözlemleyen araştırmacılara önemli doneler vermiștir.

Dünya'da ilk defa arz ve talep krizi eşanlı olarak yaşanmaktadır. Özellikle gelişmekte olan ülkelerde makroekonomik anlamda yaşanan en önemli riskin finans sektörüne olan güvenin kaybedilmesi olarak ifade edilebilir İGIAD, 2020: 6-10 Salgınla mücadele kapsamında alınan kısıtlama kararları sebebiyle reel sektörde yaşanan yavaşlama sokakta kendisini hissettirir seviyeye ulaştığı söylenebilir. Sanayi üretimi ile elektrik tüketimi arasındaki anlamlı ve pozitif ilişkiyi modelleyen literatürde yer alan çalışmalara referansla bu yavaşlama elektirik tüketiminden de takip edilebilir. TÜIKK verilerinde Nisan 2020 itibari ile elektrik tüketiminin bir önceki yılın aynı dönemine göre $\% 5,64$ azaldığı izlenmektedir (TÜİK, 2020). Elektirik tüketimindeki bu eğilim sadece Türkiye'de değil aynı zamanda salgından etkilenen ülkelerin tamamında gözlemlendi, dolayısı ile dünyayı etkileyen bir ekonomik daralmadan bahsetmek yanlış olmayacaktır. Bu daralmanın yoksul ülkelerle varsıl ülkelere etkilerinin aynı olduğunu/olacağını söylemek toptancı ve kolaycı bir yaklaşım olacaktır. Salgından nispeten daha az etkilenen Afrika kıtasındaki ülkeler, emtia fiyatlarında yaşanan gerilemeden olumsuz etkilendi. IMF Başkanı Kristalina Geor- 
gieva yaklaşık 100 ülkenin destek için IMF'ye başvurduğunu açıkladı (Ulutaş, 2020: 10-17

COVID-19 salgını nedeniyle kırılan küresel ticaret zinciri bizi genel geçer tek bir gerçeklik olmadığı olgusuyla yüzleştirerek, tek bir ekonomik kalkınma modelinin tüm dünya için genel geçer olamayacağını birkez daha gösterdi. Tek başına, dengesiz kalkınma modeli veya ihracata dayalı sanayileşme modeli veya sürdürülebilir kalkınmanın yeterli olmadığını tüm dünya yaşayarak tecrübe etmektedir. Bu noktada, ekonomik kalkınmanın gerçekleşebilmesi için Giddens'ın kavşak oluşturma çabası bir çıkış noktası olarak değerlendirilebilir. Giddens, bir taraftan doğa bilimlerinin üstünlüğüne inanarak, yöntem anlayışlarını sosyal teoriye uygun hale getirilmesi gerektiğini öne süren pozitivist görüşü önemserken diğer taraftan da sosyal bilimlerin, doğa bilimlerinden tamamen farklı, anlamaya ve yoruma dayalı bir yönteme sahip olması gerekliliğini belirten yorumsamacı yöntemi de sürece dâhil eden bir anlayışı benimsemiştir. Bu anlayış, "çifte hermeneutik" olarak nitelendirilip pozitivist ve hermeneutik yöntemlerinden oluşturulan bir anlama çabasından ibarettir (Giddens, 2002; Işık \& Serim, 2017). Giddens'den esinlenerek, kalkınma modelleri değerlendirildiğinde, tek bir modeli seçip uygulamak yerine hem ekonomideki diğer sektörlerle bağlantısı yüksek hem de ithalata olan bağımlılığı düşük, hem dönemler arası üretim zinciri benzerlik gösteren hem de çevre ve enerji kullanım emisyonları düşük ve/veya uygulanacak politikalarla düşürülebilme potansiyeli yüksek sektörleri belirlemek, bu çalışmanın temel motivasyonudur.

\section{Teorik Çerçeve ve Literatür}

Quesnay'in “Tableau Economique” ve Walras'ın tam rekabet şartlarına dayalı denge modeli temelinde, Leontief tarafından hazırlanan girdi-çıktı tablosu kullanılarak pek çok hesaplama yapılmakta ve bu hesaplamalar ülkelerin yatırım yapmak için hangi sektörlere öncelik vermesi gerektiğini göstermektedir (Quesnay, 1758; Walras, 1954; Leontief, 1936; 1949; 1970 Bu bağlamda; girdi-çıktı analizi ile dengesiz kalkınma, ihracata dayalı sanayileşme, dönemler arası üretim zincirinin benzerliği ve sürdürülebilir kalkınma için analizler yapılmaktadır.

Hirschman'a göre sektörlerin bağlantılarını hesaplanmanın en sağlıklı yolu girdi-çıktı analizi ile gerçekleşmektedir. Hirschman, dengesiz kalkınma modeli için, doğrudan geri bağlantı ve doğrudan ileri bağlantı etkisi ile hesaplanan anahtar sektörlere ağırlık verilmesinin, gelişmekte olan ülkelerin kalkınmasının ilk aşamalarında kalkınma sürecini hızlandırdığını ileri sürmüştür (Hirschman, 1978: 100-107 Chenery \& Watanabe, 1958: 493-494 Akande, 1995: 3 Rasmussen ise, toplam geri, toplam ileri bağlantı etkileri, Hazari ise bu etkilerle birlikte yayılma gücü endeksi ve yayılma hassayeti endeksini kullanarak anahtar sektörleri belirlemiştir (Rasmussen, 1956; Hazari, 1970: 302-304 
David Ricardo'nun (1891) karş̧laştırmalı üstünlükler teorisine dayanan ihracata dayalı sanayileşme modeli, bir ülkenin uluslarası rekabet gücünün fazla olduğu sektörlerde üretimin teşvik edilmesi gerektiğini belirtmiştir. Bu model, 1980'li yıllarda ticari liberalizasyon ve sanayileşme odaklı gelişmekte olan pek çok ülkede ekonomik büyüme için kullanılmıştı (Han \& Kaya, 2012: 241 Girdi-çıktı analizi ile her sektörün üretiminin ithalata hangi oranda bağımlı olduğu hesaplabailmektedi. Analiz sonucu elde edilen katsayılar ile ithalata bağımlıllğ̆ düşük olan sektörler belirlenip hangi sektörlerin ihracat odaklı teşvik mekanizmalarına dâhil edileceği hususunda karar alıcılara veri sunmaktadır (Dietzenbacher \& Los, 2000). Özellikle COVID-19 salgını ile tedarik zincirinde dikkate alınması gereken aksamaların meydana geldiği uluslararası ticaret atmosferinde ithalata bağımlılı̆̆ın azaltılması konusu müstakil olarak yeniden gündeme getirilmesi güçlendirilmek istenen milli ekonomiler açısından faydalı olabilir.

Bir sektörün, üretim zincirinin dönemler arası benzerlik göstermesi, üretim yapısında önemli bir yapısal değişimin olmadığına karine teşkil etmektedir. $\mathrm{Bu}$ amaçla Chenery ve Watanabe (1958), ülke çiftlerinin üretim yapılarını karşılaştırmak için bir Leontief Benzeşme yöntemini geliştirmiştir. Literatürde söz konusu analiz, dönemler arası üretim yapısını karşılaştırmak için de kullanılmaktadır (Altan, 1996: 73-74 Küçükkiremitçi \& Güler, 2020: 127-130

Sektörlerin üretim süreçlerini etkilemesi muhtemel dış etmenlerden birisi de Sürdürülebilir Kalkınma Hedefleri doğrultusunda uygulanan iç hukuka ve uluslararsı ticareti etkileyen regülasyonlardır. Sürdürülebilir Kalkınma ilk kez, 1987'de Birleşmiş Milletler Çevre ve Kalkınma Komisyonu'nun, Birleşmiş Milletler Genel Kurulu'na sunduğu “Ortak Geleceğimiz Raporu” ile uluslarası kamuoyunun gündemine gelmiştir. Söz konusu raporda, ekonomik kalkınmanın yanında, çevre kaynaklarını sürdürebilecek ve genişletebilecek tedbirlerin alınması, doğal kaynakların hem insanlığın bugününe hem de sürekli ilerlemesine dönük olarak gelecek projeksiyonuyla yönetilmesi ilkelerine yer verilmiştir (Dünya Çevre ve Kalkınma Komisyonu, 1987: 70-72 Ekonominin kalkınması, sektörlerin üretimine bağlıdır. Ancak her üretim beraberinde çevre açısında negatif dışsallık getirmektedir. Büyüme ve kalkınmanın çevre üzerindeki negatif dışsallığın minimize edilmesi için sektörlerin çevre üzerinde oluşturduğu stresin hesaplanması gerekmektedir. Bu hesaplama WIOD veri tabanında yer alan, çevre ve enerji kullanım emisyon verileri ile girdi-çıktı tablosu aracıllğıyla yapılabilmektedir. Söz konusu tablo yapısı gereği girdi, sermaye, teknoloji ithalat vb. gibi oranlarının sabit olduğu varsayımı ile anlık durum tespiti yapmakta, dolayısı ile elde edilen sonuçlar, sürdürülebilir kalkınma için yol göstermektedir (Korum, 1963: 9-13 TÜIK, 2020).

Girdi-çıktı analizinde temel varsayım, bir sektörün geri ve ileri bağlantılar yoluyla diğer sektörleri etkilemesidir. Bu nedenle katsayısı yüksek olan anahtar sektörlerin tüm ekonomiyi etkileyeceği öngörülmektedir. Söz konusu katsa- 
yılarla tespit edilen anahtar sektörlerin ekonomide lokomotif rol üstlenerek diğer sektörleri çekerek/iterek özellikle gelişmekte olan gelişmiş ülkelerin kalkınma sürecini hızlandırdığı düşünülebilir. Ancak gelişmekte olan ülkeler için pek çok önemli değişkenin göz ardı edildiği görülmüştür. Bu gelişmeler neticesinde anahtar sektör analizinin zayıf yönlerini saptayıp güçlendirmeye çalışan yayınlar literatürde müstakil bir yer işgal etmeye başlamıştır.

Cuello, Mansouri ve Hewings, 1992'de, Leontief ters matrisindeki büyük çarpan değerlerine duyarlılıklarını düzeltmek için Hirschman-Rasmussen anahtar sektör tanımlama endekslerini yeniden düzenlemiştir. Genelleştirilmiş anahtar sektör endeksleri, varyasyon katsayılarını hesaplamıștır.

Reyes 1996 ve 2002'de, Hirschman ve Rasmussen'in belirlediği anahtar sektörlerin kaç tane sektörle önemli derecede bağlantılı olduğu bilgisine ulaşılamadığını saptamıștır. Reyes'e göre, bağlantı katsayısının yüksek olması; ilgili sektörün sadece birkaç sektörden çokça girdi alması veya çokça çıktı satması şeklinde gerçekleşmiş olabilir. Böyle bir durumda ilgili sektörün yaratacağ etki sadece birkaç sektöre yansıyacağından, ekonomide diğer sektörleri harekete geçirmeyecektir. Reyes, önemli katsayılar yaklaşımını geliştirerek bu sorunu çözmüştür.

Sonis, Hewings ve Guo, 2000'de, Hirschman ve Rasmussen'in ayrı ayrı kriterlere göre oluşturduğu anahtar sektörlerin, farklı sektörler arasındaki ekonomik etkileşimler hakkında bilgi vermediğin vurgulamış, bu duruma bir çözüm bulmaya çalışmış, böylece klasik anahtar sektör analizinin yeni bir görüntüsünü oluşturmuştur. Geri ve ileri bağlantılarını hiyerarşik bir yapıya kavuşturarak sektörleri, anahtar sektörler, ileri bağlantı odaklı, geri bağlantı odaklı, zayıf odaklı olarak sınıflandırmıștır.

Alejandro Cardenete ve Sancho 2006'da, Leontief'in girdi-çıktı analizinde karşılıklı bağımlılık etkilerine odaklanırken, kritik bağlantıları kaçırdığını belirterek, sosyal hesaplar matrisi (SAM) oluşturmuş ve eksik gelir bağlantılarını gidermiştir.

Güler 2019'da, Reyes'in önemli katsayılar yaklaşımında, toplam geri ve toplam ileri bağlantılara önemli katsayılar yaklaşımı uygulandıktan sonra ayrı ayrı değerlendirilmemesi gerektiğini belirtmiştir. Toplam bağlantı etkileri çerçevesinde, önemli sıfatı taşıyan sektör sayıları toplanarak -keşistiği sektörleri dâhil edilmeden- bir sektörün "önemli derecede" kaç sektörü etkilediği saptanmıştır.

\section{Ekonomik Kalkınma İçin Kavşak Oluşturma Analizi}

\section{Analizin Amacı ve Özgünlüğü}

Çalışmanın temel amacı, COVID-19 pandemisi sonrası normalleşme sürecinde Türkiye ekonomisinin hızla toparlanmasına pozitif katkı sağlayacak stratejik sektörleri belirginleştirmektir. Günümüz şartlarında tek bir ekonomik kalkınma modeli yeterli olmadığı için daha önce de ifade edildiği üzere bir 
kalkınma kavşağı oluşturmaya çalışılacaktır. Etkin bir kavşak oluşturabilmek için girdi-çıktı analizi ile hesaplama imkânı olan tüm kalkınma parametreleri ayrı ayrı hesaplanmıștır. Literatürde yatırım önceliği taşıyan sektörleri belirlemek için anahtar sektörlerin düzenlenmesine yönelik çalışmalar yer almakla beraber bu çalışma olduğu gibi tüm kalkınma göstergelerini bir kavşakta toplayan bir çalışmaya rastlanmamıştır.

\section{Analizin Kapsamı ve Sinırlılıkları}

Girdi-çıktı analizi gelecekteki ekonomik aktiviteleri tahmin etmek amacıyla kullanılmakta olup, hesaplanan katsayılar çerçevesinde tahminlerin güvenilirliği, yapısal katsayıların ve nihai talebin güvenilirliğine bağlıdır (Viet, 1980: 161) Bu bağlamda, WIOD tarafından yayımlanan Türkiye'nin yurtiçi girdi-çıktı ve ithal girdi-çıktı tabloları ile çevre ve enerji kullanım emisyonu uydu hesaplarını içeren en güncel veriler kullanılmaktadır (Genty, Arto \& Neuwahl, 2012). Girdi-çıktı tablolarının tüm dünyada hazırlanması uzun yıllar almaktadır. Bu analizin temel varsayımı, girdi, sermaye, teknoloji vb. gibi oranların sabit olduğu yönündedir (Korum, 1963: 9-13 TÜIK, 2020) Analiz, üretim projeksiyonları oluşturmak için kullanılmaktadır. Çalışmada, Türkiye'nin en güncel verisi olan 2014 yılına ait girdi-çıktı tablosu ile 2016 yılına ait ${ }^{1}$ çevre ve enerji verileri kullanılmaktadır (WIOD, 2016; 2019; Corsetea \& diğerleri, 2019). WIOD veri tabanında her sektörün, yurtiçi girdi katsayıları $\left(A_{d}\right)$ ile ithalat girdi katsayıları $\left(\mathrm{A}_{\mathrm{m}}\right)$ toplanarak girdi-çıktı tablosu oluşturulmaktadır (Küçükkiremitçi \& Güler, 2020: 128-129; Dietzenbacher \& Los, 2000; Leontief, 1946; Leontief, 1953; Leontief 1985: 228; Zhao et al., 2015: 917-920). Teknoloji matrisi oluşturulduktan sonra "0" katsayısı taşıyan; temel farmasötik ürünlerin ve farmasötik preparatların imalatı, makine ve ekipmanların tamir ve montajı, posta ve kurye faaliyetleri, yayıncılık faaliyetleri, sinema filmi, video ve televizyon programı yapımı, ses kaydı ve müzik yayıncllı̆̆ faaliyetleri; programlama ve yayıncılık faaliyetleri, hukuk ve muhasebe faaliyetleri; merkez ofis faaliyetleri; yönetim danışmanlık faaliyetleri, mimari ve mühendislik faaliyetleri; teknik test ve analiz, reklam ve pazar araştırması, hanehalkının işveren olarak faaliyetleri; hanehalklarının kendi kullanımları için farklılaştırılmamış mal ve hizmet üreten faaliyetleri; uluslararası örgütler ve organların faaliyetleri hesaplamada aksaklığa neden olmaması için hem satırlardan hem de sütunlardan silinmiş böylece 46x46 matris oluşturulmuştur.

\section{Analiz Yöntemi ve Uygulaması}

Çalışmada 5 farklı analiz uygulanmıştır. İlk analiz Hirschman anahtar sektörlerinin hesaplanmasıdır. $\mathrm{Bu}$ amaçla ilk olarak teknoloji matrisi² oluştu-

1 Gerçekleştirilen çalışmada genişletilmiş çevre ve enerji girdi-çıktı tablosu kullanılmayacağı için, girdi-çıktı tablolarında 2014 verisi kullanılırken, çevre ve enerji kullanım emisyonu hesaplaması için daha güncel olan 2016 verileri kullanılmaktadır.

2 Öncelikle, x sektörünün bir birim üretim yapmak için kullandığı, y sektörünün üretimi hesaplanır. Bu şekilde her sektör için ayrı ayrı hesaplanan katsayılardan oluşan matrise teknoloji matrisi denir. Bu matrisin sütun toplamları sektörlerin DGB'sini oluştururken, satır 
rulmuştur. Bu matris aracılığı ile bir sektörün diğer sektörlerden kullandığı çıktıları gösteren toplam geri bağlantı katsayısı (DGB), ile bir sektörün çıktısının diğer sektörler açısından ne kadar önemli olduğunu gösteren toplam ileri bağlantı katsayısı (DİB) hesaplanmaktadır. Hirschman analiziyle DGB ve DİB katsayıları kullanılarak anahtar kategoriler belirlenmiștir. Söz konusu kategoriler;1.kategori: (DGB) ve (DİB) ortalamadan yüksek sektörler, 2. kategori3: DGB'si yüksek DİB'si düşük sektörler, 3. kategori: DİB'si yüksek, DGB'si düşük sektörler, 4. kategori ise DGB ve DİB'si düşük sektörlerdir (Hirschman, 1978: 100-108; Chenery \& Watanabe, 1958: 493-494). Tablo 1'de, birinci analiz neticesinde Türkiye'deki tüm sektörler Hirschman kategorileri ile sınıflandırılmıştır.

Tablo 1. Türkiye'deki Tüm Sektörlerin Hirschman Kategorileri

\begin{tabular}{|l|c|c|}
\hline SEKTÖR İSiMLERI & & \\
\hline 1.KATEGORI (ANAHTAR SEKTÖRLER) & DGB YÜKSEK & DİB YÜKSEK \\
\hline $\begin{array}{l}\text { Mobilya ve mobilya hariç, ahşap ve mantar ürünleri imalatı; } \\
\text { saz, saman ve benzeri malzemelerden örülerek yapılan } \\
\text { eşyaların imalatı }\end{array}$ & 0,7266 & 0,8023 \\
\hline Kağıt ve kağı ürünleri imalatı & 0,7080 & 1,0054 \\
\hline Kayıtlı medyanın basılması ve çoğaltılması & 0,5990 & 0,7802 \\
\hline Kok kömürü ve rafine edilmiş petrol ürünleri imalatı & 0,7994 & 1,5327 \\
\hline Kimyasal madde ve ürünlerin imalatı & 0,6834 & 1,2912 \\
\hline Kauçuk ve plastik ürünlerin imalatı & 0,7002 & 0,6238 \\
\hline Diğer metalik olmayan mineral ürünlerin imalatı & 0,6178 & 0,7906 \\
\hline Ana metal imalatı & 0,7291 & 1,2013 \\
\hline Bilgisayar, elektronik ve optik ürünlerin imalatı & 0,7453 & 0,7377 \\
\hline Elektrik, gaz, buhar ve iklimlendirme temini & 0,6839 & 0,8372 \\
\hline Taşımacılık için depolama ve destekleyici faaliyetler & 0,5295 & 0,7702 \\
\hline $\begin{array}{l}\text { Finansal hizmetlere ve sigorta faaliyetlerine yardımcı faali- } \\
\text { yetler }\end{array}$ & 0,5689 & 0,9965 \\
\hline 2.KATEGORi & DGB YÜKSEK & DíB DÜşÜK \\
\hline Gıda ürünleri, içecek ve tütün ürünleri imalatı & 0,7584 & 0,2983 \\
\hline Tekstil, giyim eşyası ve deri ürünleri imalatı & 0,7156 & 0,4528 \\
\hline Makine ve teçhizat hariç fabrikasyon metal ürünleri imalatı & 0,6684 & 0,5089 \\
\hline Elektrikli teçhizat imalatı & 0,6840 & 0,4918 \\
\hline Başka yerde sınıflandırılmamış makine ve ekipman imalatı & 0,5992 & 0,3122 \\
\hline Motorlu kara taşıtları, römork ve yarı römork imalatı & 0,7339 & 0,3323 \\
\hline
\end{tabular}

toplamları sektörlerin DỉB'sini oluşturur.

3 Hirschman'ın ekonomik kalkınmada, sektörlerin geri bağlantılarına daha büyük önem verdiği için, DGB'si yüksek sektörlerin ikinci kategoride yer alırken, DİB'si yüksek sektörlerin üçüncü kategoride yer almaktadır. 


\begin{tabular}{|c|c|c|}
\hline Mobilya imalatı; diğer imalatlar & 0,7286 & 0,0970 \\
\hline İnşaat & 0,5329 & 0,0660 \\
\hline Hava Taşımacılığı & 0,6357 & 0,4644 \\
\hline Konaklama ve yemek servisi faaliyetleri & 0,5344 & 0,1758 \\
\hline 3. KATEGORİ & DGB DÜŞÜK & DİB YÜKSEK \\
\hline Ormancllık ve tomrukçuluk & 0,1399 & 0,7173 \\
\hline Madencilik ve taş ocakçılı̆̆ı & 0,3770 & 0,9049 \\
\hline Diğer ulaşım araçlarının imalatı & 0,4980 & 0,6993 \\
\hline Su toplama, aritma ve temini & 0,1845 & 0,6878 \\
\hline Kanalizasyon; atık toplama, işleme ve bertaraf faaliyetleri & 0,4829 & 0,6663 \\
\hline $\begin{array}{l}\text { Motorlu kara taşıtlarının ve motosikletlerin toptan ve perak- } \\
\text { ende ticareti ve onarımı }\end{array}$ & 0,4239 & 0,6387 \\
\hline Motorlu kara taşıtları ve motosikletler hariç toptan ticaret & 0,3802 & 0,6554 \\
\hline Su ulaştırma & 0,3855 & 0,8321 \\
\hline $\begin{array}{l}\text { Bilgisayar programlama, danışmanlık ve ilgili faaliyetler; bilgi } \\
\text { hizmeti faaliyetleri }\end{array}$ & 0,3398 & 0,6793 \\
\hline Sigorta ve emeklilik fonları hariç finansal hizmet faaliyetleri & 0,3520 & 0,7049 \\
\hline $\begin{array}{l}\text { Zorunlu sosyal güvenlik hariç sigorta, reasürans ve emeklilik } \\
\text { fonları }\end{array}$ & 0,3588 & 0,7385 \\
\hline Bilimsel araştırma ve geliştirme & 0,4052 & 1,6124 \\
\hline $\begin{array}{l}\text { Diğer mesleki, bilimsel ve teknik faaliyetler; veterinerlik } \\
\text { hizmetleri }\end{array}$ & 0,3376 & 0,8383 \\
\hline İdari ve destek hizmet faaliyetleri & 0,3971 & 0,6756 \\
\hline 4. KATEGORİ & DGB DÜŞÜK & DİB DÜŞÜK \\
\hline $\begin{array}{l}\text { Bitkisel ve hayvansal üretim ile avcılık ve ilgili hizmet faali- } \\
\text { yetleri }\end{array}$ & 0,3314 & 0,5978 \\
\hline Balıkçılık ve su ürünleri yetiştiriciliği & 0,2301 & 0,2697 \\
\hline $\begin{array}{l}\text { Perakende ticaret (motorlu kara taşıtları ve motosikletler } \\
\text { hariç) }\end{array}$ & 0,3809 & 0,4482 \\
\hline Kara taşımacılığı ve boru hatları ile ulaşım & 0,4000 & 0,4943 \\
\hline Telekomünikasyon & 0,4420 & 0,5317 \\
\hline Gayrimenkul faaliyetleri & 0,1529 & 0,2064 \\
\hline Kamu yönetimi ve savunma; zorunlu sosyal güvenlik & 0,3934 & 0,0105 \\
\hline Eğitim & 0,1986 & 0,0442 \\
\hline İnsan sağlı̆̆ı ve sosyal hizmet faaliyetleri & 0,4741 & 0,0727 \\
\hline Diğer hizmet faaliyetleri & 0,4501 & 0,3037 \\
\hline
\end{tabular}

Kaynak: WIOD 2016 verileri kullanılarak yazarlar tarafindan hesaplanmıştır.

Tablo 1'de Türkiye'deki tüm sektörler Hirschman kategorileri ile sınıflandırılmıştır. COVID-19 salgını ile mücadelede talebi artan dezenfektan gibi hijyen ürünlerinin imalatını üstelenen kimyasal madde ve ürünlerin imalatı sektörü, solunum cihazı üretiminin gerçekleşmesini sağlayan ana metal imalatı, 
bilgisayar, elektronik ve optik ürünlerin imalatı sektörleri, hastanelerde için üretilen kullan-at çarşaf, havlu vb. gibi malzemelerin üretimini sağlayan kâğıt ve kâğıt ürünleri imalatı sektörleri Hirschman'ın anahtar sektörler kategorisinde yer almaktadır.

İkinci analiz ise Rasmussen anahtar sektörlerinin hesaplanmasıdır. Bu amaçla Leontief ters matrisi ${ }^{4}$ oluşturulmuştur. Bu matris aracıllğı ile bir birimlik nihai talep artışının ekonomide neden olduğu toplam üretim artışı şeklinde ifade edilen toplam geri bağlantı etkisi (TGB) ile tüm sektörlerdeki birer birimlik nihai talep artışlarının belli bir sektörün üretiminde sebep olduğu artış şeklinde ifade eden toplam ileri bağlantı etkisi (TiB) hesaplanmaktadır (Küçükkiremitçi, 2011: 12 Küçükkiremitçi, Karaca \& Eşiyok, 2010: 3-5). U Ue $\mathrm{U}_{\mathrm{i}}$ katsayılar1 ${ }^{5}$ kullanılarak Rasmussen anahtar sektör kategorileri belirlenmiştir (Rasmussen, 1956). Hazari, toplam bağlantı katsayısı ile ekonomiye yayılacak etkinin yüksek olmasının yanında, bu katagoriye düşük değişim katsayısını da eklemenin gerekliliğini ifade etmiștir. Bu bağlamda, toplam geri bağlantı değişim katsayısı, $V_{j}$ ile ifade edilmektedir. Formül şu şekilde gösterilmektedir:

$$
V_{j}=\frac{\sqrt{\frac{1}{m-1} \sum_{i=1}^{m}\left(K i j-\frac{1}{m} \sum_{i=1}^{m} K i j\right)^{2}}}{\frac{1}{m} \sum_{i=1}^{m} K i j}
$$

Toplam ileri bağlantı değişim katsayısı ise $\mathrm{V}_{\mathrm{i}}$ ile ifade edilmektedir (Hazari, 1970: 302). Formül şu şekilde gösterilmektedir:

$$
V_{i}=\frac{\sqrt{\frac{1}{m-1} \sum_{j=1}^{m}\left(K i j-\frac{1}{m} \sum_{j=1}^{m} K i j\right)^{2}}}{\frac{1}{m} \sum_{\substack{j=1 \\(i=1, \ldots, m)}}^{m} K_{j}}
$$

Rasmussen kategorileri şu şekildedir; $U_{j}>1, U_{i}>1$ ile $V_{j} v e V_{i}$ düşük ise anahtar sektör, $U_{j}>1, U_{i}<1$ ile $V_{j} v e V_{i \text { düşük }}$ ise sektörler arası arza bağımlı, $U_{j}<1, U_{i}>1$ ile $V_{j}$ ve $V_{i}$ düşük ise sektörler arası talebe bağımlı, $U_{j}<1, U_{i}<1$ ile $V_{j} v e V_{i}$ düşük ise sektörler genel olarak bağımsızdır (Rasmussen, 1956; Hazari, 1970: 302).

4 x sektörü ürününe olan bir birimlik nihai talep artışının, y sektörü üretiminde ne kadarlık artışa neden olacağını ifade eder. Bu şekilde her sektör için ayrı ayrı hesaplanan katsayılardan oluşan matrise, Leontief ters matrisi adı verilir. Bu matrisin sütun toplamları sektörlerin TGB'sini oluștururken, satır toplamları sektörlerin TiB'sini olușturur.

5 TGB katsayıları her sektör için kısmi olarak değerlendirerek ve ilgili sektörlerin ortalamasına bölünerek normalize edilir, Uj katsayısına ulaşılır. Aynı işlem TỉB katsayıları için uygulanarak Ui katsayısına ulaşılır. 
Tablo 2'de, Türkiye'nin Rasmussen kategorilerine göre anahtar sektörleri gösterilmektedir.

Tablo 2. Türkiye'deki Sektörlerin Rasmussen Kategorileri

\begin{tabular}{|c|c|c|c|c|}
\hline SEKTÖR İSIMLERİ & & & & \\
\hline 1.KATEGORİ (ANAHTAR SEKTÖRLER) & $\mathrm{BL}_{\mathrm{j}} \geq \mathbf{1}$ & $\mathbf{F L}_{\mathrm{i}} \geq \mathbf{1}$ & $\mathbf{v}_{\mathbf{j}}$ & $\mathbf{V}_{\mathbf{i}}$ \\
\hline Tekstil, giyim eşyası ve deri ürünleri imalatı & 1,3186 & 1,3270 & 4,0737 & 4,0182 \\
\hline Kağıt ve kağıt ürünleri imalatı & 1,2524 & 1,0918 & 3,3801 & 3,8851 \\
\hline Kok kömürü ve rafine edilmiş petrol ürünleri imalatı & 1,2445 & 1,4875 & 3,3508 & 2,5968 \\
\hline Kimyasal madde ve ürünlerin imalatı & 1,1996 & 2,3064 & 3,8071 & 2,0384 \\
\hline Ana metal imalatı & 1,3251 & 2,1355 & 3,8795 & 2,5831 \\
\hline Bilgisayar, elektronik ve optik ürünlerin imalatı & 1,3494 & 1,0487 & 3,6697 & 4,7182 \\
\hline Elektrik, gaz, buhar ve iklimlendirme temini & 1,2858 & 1,9822 & 4,8313 & 3,0809 \\
\hline 2.KATEGORİ & $B L_{j} \geq 1$ & $\mathrm{FL}_{\mathrm{i}}<1$ & $\mathbf{V j}$ & $\mathbf{V i}$ \\
\hline Gıda ürünleri, içecek ve tütün ürünleri imalatı & 1,1901 & 0,9513 & 3,4846 & 4,1239 \\
\hline $\begin{array}{l}\text { Mobilya ve mobilya hariç, ahşap ve mantar ürünleri } \\
\text { imalatı; saz, saman ve benzeri malzemelerden örülerek } \\
\text { yapılan eşyaların imalatı }\end{array}$ & 1,2200 & 0,6779 & 3,1666 & 5,6318 \\
\hline Kayıtlı medyanın basılması ve çoğaltılması & 1,1189 & 0,7208 & 3,1135 & 4,7123 \\
\hline Kauçuk ve plastik ürünlerin imalatı & 1,2491 & 0,8402 & 3,0019 & 4,1432 \\
\hline Diğer metalik olmayan mineral ürünlerin imalatı & 1,1100 & 0,8767 & 3,3567 & 4,2174 \\
\hline $\begin{array}{l}\text { Makine ve teçhizat hariç fabrikasyon metal ürünleri } \\
\text { imalatı }\end{array}$ & 1,2467 & 0,7054 & 2,9697 & 4,7976 \\
\hline Elektrikli teçhizat imalatı & 1,2395 & 0,7007 & 2,9579 & 5,1391 \\
\hline $\begin{array}{l}\text { Başka yerde sınıflandırılmamış makine ve ekipman } \\
\text { imalatı }\end{array}$ & 1,1505 & 0,7387 & 3,1292 & 4,7089 \\
\hline Motorlu kara taşıtları, römork ve yarı römork imalatı & 1,3146 & 0,7138 & 2,9889 & 5,4016 \\
\hline Diğer ulaşım araçlarının imalatı & 1,0102 & 0,5619 & 3,3884 & 6,1017 \\
\hline Mobilya imalatı; diğer imalatlar & 1,3153 & 0,5282 & 2,6648 & 6,2497 \\
\hline İnşaat & 1,0479 & 0,6173 & 3,1652 & 5,3691 \\
\hline Hava Taşımacilığı & 1,0963 & 0,6409 & 3,1715 & 5,3396 \\
\hline Konaklama ve yemek servisi faaliyetleri & 1,0046 & 0,7780 & 3,3089 & 4,1976 \\
\hline 3. KATEGORİ & $B L j<1$ & $\mathbf{F L i} \geq 1$ & $\mathbf{V j}$ & $\mathbf{V i}$ \\
\hline $\begin{array}{l}\text { Bitkisel ve hayvansal üretim ile avcıllk ve ilgili hizmet } \\
\text { faaliyetleri }\end{array}$ & 0,7950 & 1,0921 & 4,7778 & 3,7117 \\
\hline Madencilik ve taş ocakçllığı & 0,8681 & 1,5031 & 3,9281 & 2,4217 \\
\hline $\begin{array}{l}\text { Motorlu kara taşitlarının ve motosikletlerin toptan ve } \\
\text { perakende ticareti ve onarımı }\end{array}$ & 0,8750 & 1,0762 & 3,8963 & 3,1328 \\
\hline $\begin{array}{l}\text { Motorlu kara taşıtları ve motosikletler hariç toptan } \\
\text { ticaret }\end{array}$ & 0,8251 & 1,8687 & 4,1068 & 1,7675 \\
\hline $\begin{array}{l}\text { Perakende ticaret (motorlu kara taşıtları ve moto- } \\
\text { sikletler hariç) }\end{array}$ & 0,8134 & 1,4130 & 4,0570 & 2,2978 \\
\hline Kara taşımacılığı ve boru hatları ile ulaşım & 0,8731 & 2,4642 & 4,3153 & 1,4783 \\
\hline Taşımacılık için depolama ve destekleyici faaliyetler & 0,9860 & 1,3119 & 4,2279 & 3,1247 \\
\hline $\begin{array}{l}\text { Sigorta ve emeklilik fonları hariç finansal hizmet } \\
\text { faaliyetleri }\end{array}$ & 0,7866 & 1,4142 & 4,4683 & 2,4752 \\
\hline Gayrimenkul faaliyetleri & 0,6381 & 1,0563 & 5,1598 & 3,0721 \\
\hline
\end{tabular}




\begin{tabular}{|l|c|c|c|c|}
\hline $\begin{array}{l}\text { Diğer mesleki, bilimsel ve teknik faaliyetler; veteriner- } \\
\text { lik hizmetleri }\end{array}$ & 0,8248 & 1,7056 & 4,1931 & 1,9814 \\
\hline İdari ve destek hizmet faaliyetleri & 0,8390 & 1,1536 & 4,6038 & 3,3062 \\
\hline 4. KATEGORi & $\mathbf{B L j}<\mathbf{1}$ & $\mathbf{F L i}<\mathbf{1}$ & $\mathbf{V j}$ & $\mathbf{V i}$ \\
\hline Ormancllı ve tomrukçuluk & 0,6143 & 0,5991 & 5,3406 & 5,5145 \\
\hline Balıkçılık ve su ürünleri yetiştiriciliği & 0,7117 & 0,4928 & 4,6188 & 6,7089 \\
\hline Su toplama, arıtma ve temini & 0,6859 & 0,5809 & 4,7544 & 5,6158 \\
\hline $\begin{array}{l}\text { Kanalizasyon; atık toplama, işleme ve bertaraf faali- } \\
\text { yetleri }\end{array}$ & 0,9638 & 0,5836 & 4,0418 & 6,6695 \\
\hline Su ulaştırma & 0,8519 & 0,8511 & 4,1822 & 4,1433 \\
\hline Telekomünikasyon & 0,9002 & 0,9355 & 3,8759 & 3,6798 \\
\hline $\begin{array}{l}\text { Bilgisayar programlama, danışmanlık ve ilgili faali- } \\
\text { yetler; bilgi hizmeti faaliyetleri }\end{array}$ & 0,7989 & 0,5669 & 4,0984 & 5,7802 \\
\hline $\begin{array}{l}\text { Zorunlu sosyal güvenlik hariç sigorta, reasürans ve } \\
\text { emeklilik fonları }\end{array}$ & 0,7952 & 0,5410 & 4,1078 & 6,0430 \\
\hline $\begin{array}{l}\text { Finansal hizmetlere ve sigorta faaliyetlerine yardımcl } \\
\text { faaliyetler }\end{array}$ & 0,9888 & 0,6077 & 3,5979 & 5,8203 \\
\hline Bilimsel araştırma ve geliştirme & 0,9000 & 0,4848 & 3,6095 & 6,7522 \\
\hline Kamu yönetimi ve savunma; zorunlu sosyal güvenlik & 0,8659 & 0,5043 & 3,7388 & 6,4887 \\
\hline Eğitim & 0,6757 & 0,5324 & 4,8301 & 6,1581 \\
\hline İnsan sağlığı ve sosyal hizmet faaliyetleri & 0,9433 & 0,5378 & 3,5337 & 6,2341 \\
\hline Diğer hizmet faaliyetleri & 0,8913 & 0,6924 & 4,2151 & 5,4324 \\
\hline
\end{tabular}

Kaynak: WIOD 2016 verileri kullanılarak yazarlar tarafindan hesaplanmıştır.

Tablo 2 incelendiğinde Rasmussen kriterlerine göre hesaplanmış olan anahtar sektörlerin içerisinde salgınla mücadelede etkin rol alan sektörlerin belirginleştiği gözlemlenebilmektedir. Bu sektörler, maske ve tıbbi personeli korumak için kıyafet üretiminin yapıldığı tekstil, giyim eşyası ve deri ürünleri imalatı sektörü; Hirschman'ın anahtar sektörler kategorisinde de yer alan dezenfektan gibi hijyen ürünlerinin imalatını gerçekleştiren kimyasal madde ve ürünlerin imalatı sektörü; solunum cihazı üretiminde paydaş olan ana metal imalatı, bilgisayar, elektronik ve optik ürünlerin imalatı sektörleri; hastanelerde bir kerelik kullanım amaçlı üretilen kullan-at çarşaf, havlu vb. gibi malzemelerin üretimini sağlayan kağıt ve kağıt ürünleri imalatı sektörleri şeklinde sıralanabilir. Bu kategoride yer alan diğer sektörler; kok kömürü ve rafine edilmiş petrol ürünleri, elektrik, gaz, buhar ve iklimlendirme temini sektörleridir.

Üçüncü analiz önemli bir aşama olup üretimin ithalata bağımlılığının hesaplanmasıdır. İthalat girdi-çıtı tablosu, ithalatı yapılan mal ve hizmetlerin hangi ürün ve hizmetlerin imalatında kullanıldığını ve hangi nihaî talep unsurları tarafından kullanıldığını gösterir. Bu şekilde, bir birim üretim artışının sebep olduğu ithal girdi talebinde meydana gelen artışa ve doğrudan üretim girdileri içinde ithal girdilerin payına ulaşılmaktadır. Tüm sektörler için hesaplandığında, Türkiye ekonomisindeki 46 sektörün üretiminin ithalata olan 
bağımlılığına ulaşılmaktadır (Leontief, 1953: 65-67 Küçükkiremitçi \& Güler, 2020: 122-129).

İhracata dayalı sanayileşme, bir ekonominin bir taraftan iç talebi karşılarken diğer taraftan ürettiği ürünleri dış pazarlara ihraç edebilmesi prensibine dayanmaktadır. Ancak COVID-19 salgının da olduğu gibi ithal ara girdiye yüksek bağımlılığı olan ekonomiler küresel arz zincirinde aksamaların meydana geldiği olağanüstü koşullarda imalata dayalı sektörlerin faaliyetlerinde istenmeyen durumlar ortaya çıkabilmektedir. $\mathrm{Bu}$ gibi dönemlerde üretiminde ithalata bağımlılı̆̆ı az olan sektörler ekonominin geri kalanı için lokomotif olabilmektedir. Stratejik önemi haiz sektörlerde ara girdinin ithalata bağımlılığı yüksek olması durumunda ihtiyaç duyulan ara girdinin yerli ve milli imkânlarla üretilmesi için gerekli müşevvik mekanizmaları devreye sokulmalıdır. Sektörlerin ithalata bağımlılık seviyelerini gösteren analizler karar alıcılara da yardımcı olabilir. Bu çerçevede Tablo 3'de, Türkiye ekonomisinde yer alan tüm sektörlerin toplam üretim içindeki ithalata bağımlılık durumları küçükten büyüğe doğru sıralanmaktadır.

Tablo 3. Türkiye Ekonomisinde Yer Alan Tüm Sektörlerin Toplam Üretim İçindeki İthalata Bağımlılık Katsayıları

\begin{tabular}{|l|c|}
\hline SEKTÖR İsiMLERİ & $\begin{array}{c}\text { İthalata } \\
\text { Bağımlılık }\end{array}$ \\
\hline Zorunlu sosyal güvenlik hariç sigorta, reasürans ve emeklilik fonları & 0,0156 \\
\hline Ormancılık ve tomrukçuluk & 0,0176 \\
\hline Sigorta ve emeklilik fonları hariç finansal hizmet faaliyetleri & 0,0180 \\
\hline Eğitim & 0,0241 \\
\hline Taşımaclık için depolama ve destekleyici faaliyetler & 0,0250 \\
\hline Motorlu kara taşıtları ve motosikletler hariç toptan ticaret & 0,0267 \\
\hline Diğer hizmet faaliyetleri & 0,0279 \\
\hline İdari ve destek hizmet faaliyetleri & 0,0301 \\
\hline Perakende ticaret (motorlu kara taşıtları ve motosikletler hariç) & 0,0310 \\
\hline Gayrimenkul faaliyetleri & 0,0313 \\
\hline Finansal hizmetlere ve sigorta faaliyetlerine yardımcı faaliyetler & 0,0341 \\
\hline $\begin{array}{l}\text { Bilgisayar programlama, danışmanlık ve ilgili faaliyetler; bilgi hizmeti faali- } \\
\text { yetleri }\end{array}$ & 0,0434 \\
\hline $\begin{array}{l}\text { Motorlu kara taşıtlarının ve motosikletlerin toptan ve perakende ticareti ve } \\
\text { onarımı }\end{array}$ & 0,0466 \\
\hline Su toplama, arıtma ve temini & 0,0515 \\
\hline Balıkçılık ve su ürünleri yetiştiriciliği & 0,0525 \\
\hline Elektrik, gaz, buhar ve iklimlendirme temini & $\mathbf{0 , 0 5 4 6}$ \\
\hline Telekomünikasyon & 0,0553 \\
\hline
\end{tabular}




\begin{tabular}{|c|c|}
\hline Bilimsel araştırma ve geliştirme & 0,0589 \\
\hline Kamu yönetimi ve savunma; zorunlu sosyal güvenlik & 0,0611 \\
\hline Konaklama ve yemek servisi faaliyetleri & 0,0619 \\
\hline Kara taşımacılığı ve boru hatları ile ulaşım & 0,0659 \\
\hline Diğer mesleki, bilimsel ve teknik faaliyetler; veterinerlik faaliyetleri & 0,0683 \\
\hline Su ulaştırma & 0,0694 \\
\hline Bitkisel ve hayvansal üretim ile avcllık ve ilgili hizmet faaliyetleri & 0,0782 \\
\hline İnsan sağlığı ve sosyal hizmet faaliyetleri & 0,0834 \\
\hline Madencilik ve taş ocakçılığı & 0,0883 \\
\hline Hava Taşımacılığı & 0,0935 \\
\hline Kanalizasyon; atık toplama, işleme ve bertaraf faaliyetleri & 0,1019 \\
\hline Gıda ürünleri, içecek ve tütün ürünleri imalatı & 0,1106 \\
\hline Kayıtlı medyanın basılması ve çoğaltılması & 0,1291 \\
\hline Tekstil, giyim eşyası ve deri ürünleri imalatı & 0,1293 \\
\hline Diğer metalik olmayan mineral ürünlerin imalatı & 0,1294 \\
\hline İnşaat & 0,1518 \\
\hline Kağıt ve kağıt ürünleri imalatı & 0,1865 \\
\hline Diğer ulaşım araçlarının imalatı & 0,1931 \\
\hline $\begin{array}{l}\text { Mobilya ve mobilya hariç, ahşap ve mantar ürünleri imalatt; saz, saman ve benzeri } \\
\text { malzemelerden örülerek yapilan eșyaların imalatı }\end{array}$ & 0,1993 \\
\hline Kok kömürü ve rafine edilmiş petrol ürünleri imalatı & 0,2053 \\
\hline Kimyasal madde ve ürünlerin imalatı & 0,2773 \\
\hline Başka yerde sınıflandırılmamış makine ve ekipman imalatı & 0,2793 \\
\hline Elektrikli teçhizat imalatı & 0,2830 \\
\hline Mobilya imalatı; diğer imalatlar & 0,2946 \\
\hline Kauçuk ve plastik ürünlerin imalatı & 0,3152 \\
\hline Makine ve teçhizat hariç fabrikasyon metal ürünleri imalatı & 0,3330 \\
\hline Motorlu kara taşıtları, römork ve yarı römork imalatı & 0,3489 \\
\hline Bilgisayar, elektronik ve optik ürünlerin imalatı & 0,3510 \\
\hline Ana metal imalatı & 0,3598 \\
\hline
\end{tabular}

Kaynak: WIOD 2016 verileri kullanılarak yazarlar tarafindan hesaplanmıştır.

Girdi ve çıtı işlemlerinin oluşturduğu bütünü temsil ettiği için hizmet sektörleri de hesaplamaya dâhil edilmektedir. Ancak söz konusu sektörler, sadece hizmete yönelik olduğu için çok düşük ithal bağımlılığa sahiptir. İmalata konu olan sektörlerin birçoğunda küreselleşmenin de etkisiyle ithalata bağımlılığın yüksek olduğu görülmektedir.

Nihaî analiz neticesinde ulaşılmaya çalışılan ekonomik kalkınma kavşağı için hem doğrudan geri bağlantı katsayısı hem de doğrudan ileri bağlantı katsayısının yüksek olan sektörlerin ön plana çıkarılması, bu sekötrler içinde de ithalata 
bağımlılığı düşük sekötrlerin belirginleştirilmesi gerekmektedir. Bu amaçla Hirschman anahtar sektörler analizinde ve Rasmussen anahtar sektörler analizinde ulaşlan sektörler ithalata bağımlılıklarına göre düşükten büyüğe göre sıralanarak her iki analizin kesişim kümesinde yer alan sektörler belirlenmiştir. Bu çerçevede 7 sektör ekonomik kalkınma kavşağında yer alma potansiyeli taşımaktadır. Söz konusu 7 sektör ve bu sektörlerin en çok ithal girdi kullandı̆̆ ilk 3 sektör Tablo 4'de gösterilmektedir.

Tablo 4. Ekonomik Kavşakta Yer Alma Potansiyeli Yüksek Olan Sektörlerin En Çok İthal Girdi Kullandığı Sektörler

\begin{tabular}{|c|c|c|}
\hline $\begin{array}{l}\text { Ekonomik Kavşakta Yer } \\
\text { Alma Potansiyeli Yüksek } \\
\text { Olan Sektörler }\end{array}$ & $\begin{array}{l}\text { Ekonomik Kavşakta Yer Alma Potansiyeli } \\
\text { Yüksek Olan Sektörlerin En Çok Girdi } \\
\text { Kullandığı Sektörler }\end{array}$ & Katsayı \\
\hline \multirow{3}{*}{$\begin{array}{l}\text { Elektrik, gaz, buhar ve } \\
\text { iklimlendirme temini }\end{array}$} & Madencilik ve taş ocakçılığı & 0,0206 \\
\hline & Elektrikli teçhizat imalatı & 0,0087 \\
\hline & $\begin{array}{l}\text { Başka yerde sınıflandırılmamış makine ve } \\
\text { ekipman imalatı }\end{array}$ & 0,0046 \\
\hline \multirow{3}{*}{$\begin{array}{l}\text { Tekstil, giyim eşyası ve deri } \\
\text { ürünleri imalatı }\end{array}$} & Kimyasal madde ve ürünlerin imalatı & 0,0542 \\
\hline & Tekstil, giyim eşyası ve deri ürünleri imalatı & 0,0419 \\
\hline & $\begin{array}{l}\text { Kok kömürü ve rafine edilmiş petrol ürünleri } \\
\text { imalatı }\end{array}$ & 0,0113 \\
\hline \multirow{3}{*}{ Kağıt ve kağıt ürünleri imalatı } & Kağıt ve kağıt ürünleri imalatı & 0,0778 \\
\hline & Kimyasal madde ve ürünlerin imalatı & 0,0538 \\
\hline & $\begin{array}{l}\text { Kok kömürü ve rafine edilmiş petrol ürünleri } \\
\text { imalatı }\end{array}$ & 0,0145 \\
\hline \multirow{3}{*}{$\begin{array}{l}\text { Kok kömürü ve rafine edilmiş } \\
\text { petrol ürünleri imalatı }\end{array}$} & $\begin{array}{l}\text { Kok kömürü ve rafine edilmiş petrol ürünleri } \\
\text { imalatı }\end{array}$ & 0,0929 \\
\hline & Madencilik ve taş ocakçılığı & 0,0733 \\
\hline & Kimyasal madde ve ürünlerin imalatı & 0,0162 \\
\hline \multirow{3}{*}{$\begin{array}{l}\text { Kimyasal madde ve ürünlerin } \\
\text { imalatı }\end{array}$} & Kimyasal madde ve ürünlerin imalatı & 0,2051 \\
\hline & $\begin{array}{l}\text { Kok kömürü ve rafine edilmiş petrol ürünleri } \\
\text { imalatı }\end{array}$ & 0,0196 \\
\hline & $\begin{array}{l}\text { Motorlu kara taşıtları ve motosikletler hariç } \\
\text { toptan ticaret }\end{array}$ & 0,0081 \\
\hline \multirow{3}{*}{$\begin{array}{l}\text { Bilgisayar, elektronik ve optik } \\
\text { ürünlerin imalatı }\end{array}$} & $\begin{array}{l}\text { Bilgisayar, elektronik ve optik ürünlerin } \\
\text { imalatı }\end{array}$ & 0,2394 \\
\hline & Ana metal imalatı & 0,0313 \\
\hline & Elektrikli teçhizat imalatı & 0,0167 \\
\hline \multirow{3}{*}{ Ana metal imalatı } & Ana metal imalatı & 0,2952 \\
\hline & Kimyasal madde ve ürünlerin imalatı & 0,0099 \\
\hline & $\begin{array}{l}\text { Başka yerde sınıflandırılmamış makine ve } \\
\text { ekipman imalatı }\end{array}$ & 0,0077 \\
\hline
\end{tabular}

Kaynak: WIOD 2016 verileri kullanılarak yazarlar tarafindan hesaplanmıştır. 
Bu tablodan hareketle ekonomik kavşakta yer alma potansiyeli yüksek olan sektörlerin en çok ithal girdiyi yine kendi sektörlerinden talep ettiği söylenebilir.

Dördüncü analizde, oluşturulan ekonomik kalkınma kavşakta yer alma potansiyeli yüksek olan sektörlerin dönemler arası üretim zincirlerindekí benzerlikleri ve üretimde yapısal değişim olup olmadığını gözlemlememize yardımcı olan Leontief benzeşme analizi ve Mann Whitney-U testi uygulanacaktır. Dönemler arası benzerlik analizini gerçekleştirmek için WIOD veri tabanında yer alan Türkiye için yayımlanan 2000 yılına ait ilk girdi-çıktı tablosu ile 2014 yılına ait son girdi-çıktı tablosu kullanılmıştır. Öncelikle her iki tabloda TGB katsayıları hesaplanmış ve dönemler arası üretim zincirinin benzerliğini analiz etmek için Chenery ve Watanabe'nin kullandığı formüldeki ülkeleri ifade eden notasyonlar yerine, dönemleri ifade eden notasyonlar kullanılmıştır (Leontief, 1951; Bezdek, 1984: 502-505).

Formül şu şekildedir:

$$
P_{j}=\frac{\sum_{i=1}^{n}\left|a j^{t+1}-a i j\right|}{1 / 2 \sum_{i=1}^{n}\left(a_{i j}{ }^{t+1}+a_{i j} t\right)}
$$

Formülde yer alan t, 2000 yılının TGB katsayılarını, t+1 ise 2014 yılının TGB katsayılarını ifade etmektedir. Analizde, elde edilen katsayılar küçüldükçe dönemler arası benzerliğin arttığı belirtilmekle beraber eşik değer belirtilmediği için bir zafiyet söz konusu olmaktadır. Bu zafiyeti gidermek ve çalışmayı sağlam bir yapıya oturmak amacıyla; öncelikle doğru istatistik yönteminin uygulanabilmesi için 2000 yılı TGB ve 2014 yılı TGB katsayılarının normal dağılıma uygunluk gösterip göstermediği Shapiro-Wilk testi ile sınanmıştır. Test sonucunda normal dağılıma uygunluk göstermediği tespit elimiştir. Bu sonuç çerçevesinde, 2000 yılı TGB ve 2014 yılı TGB katsayılarının karşılaştırmak için Mann Whitney-U testi uygulanmış hesaplamada SPSS 23 yazılımı kullanılmıştır (Gamgam \& Altunkaynak, 2012: 156-157). Kullanılan formül: $\mathrm{T}=\mathrm{S}-\left[\mathrm{n}_{1}\left(\mathrm{n}_{1}+1\right)\right] / 2$

Oluşturulan ekonomik kavşakta yer alan sektörlerin küçükten büyüğe doğru sıralanmış Leontief Benzeşme Testi, Shapiro-Wilk Testi ve Mann Whitney-U Testi sonuçları Tablo 5'de bir arada gösterilmektedir.

6 Bir sektörün toplam geri bağlantı etkisi aynı zamanda, ilgili sektörün üretim zincirini de göstermektedir. Zinciri oluşturan sektörlerdeki bir tek ürüne olan nihai talepteki farklılaşma tüm sektörleri etkilemektedir.

7 Ülkeler arasındaki üretim yapısının benzerliği ile ilgili ilk formülü Leontief oluşturmuştur. Chenery Watanabe, pay bölümünü mutlak değer içerisine almıştır. 
Tablo 5. Ekonomik Kavşakta Yer Alma Potansiyeli Yüksek Olan Sektörlerin, Üretim Zincirinin, Dönemler Arası Değişimi

\begin{tabular}{|c|c|c|c|c|c|c|}
\hline \multirow[b]{2}{*}{ Sektör İsimleri } & \multirow{2}{*}{$\begin{array}{c}\text { Leontief } \\
\text { Benzeşme } \\
\text { Testi }\end{array}$} & \multirow{2}{*}{$\begin{array}{l}\text { Shapiro } \\
\text { Wilk } \\
\text { Testi }\end{array}$} & \multicolumn{4}{|c|}{ Mann Whitney Testi } \\
\hline & & & $\begin{array}{l}2000 \text { Rank } \\
\text { Ortalaması }\end{array}$ & $\begin{array}{l}2014 \text { Rank } \\
\text { Ortalaması }\end{array}$ & $\underset{\text { değeri }}{z}$ & p-değeri \\
\hline $\begin{array}{l}\text { Tekstil, giyim } \\
\text { eşyası ve deri } \\
\text { ürünleri imalatı }\end{array}$ & 11,8557 & 0,1649 & 65,048 & 59,952 & $-0,787$ & 0,431 \\
\hline $\begin{array}{l}\text { Elektrik, gaz, } \\
\text { buhar ve } \\
\text { iklimlendirme } \\
\text { temini }\end{array}$ & 12,3338 & 0,1526 & 62,968 & 62,032 & $-0,142$ & 0,887 \\
\hline $\begin{array}{l}\text { Kağt ve kağt } \\
\text { ürünleri imalatı }\end{array}$ & 12,6535 & 0,1941 & 63,790 & 61,210 & $-0,397$ & 0,691 \\
\hline $\begin{array}{l}\text { Kok kömürü ve } \\
\text { rafine edilmiş } \\
\text { petrol ürünleri } \\
\text { imalatı }\end{array}$ & 13,1504 & 0,2292 & 66,145 & 58,855 & $-1,127$ & 0,260 \\
\hline $\begin{array}{l}\text { Kimyasal madde } \\
\text { ve ürünlerin } \\
\text { imalatı }\end{array}$ & 12,6589 & 0,1930 & 64,613 & 60,387 & $-0,652$ & 0,514 \\
\hline $\begin{array}{l}\text { Bilgisayar, } \\
\text { elektronik ve } \\
\text { optik ürünlerin } \\
\text { imalatı }\end{array}$ & 12,8110 & 0,1871 & 64,968 & 60,032 & $-0,762$ & 0,446 \\
\hline Ana metal imalatı & 13,2159 & 0,1676 & 65,177 & 59,823 & $-0,827$ & 0,408 \\
\hline
\end{tabular}

Kaynak: WIOD 2016 verileri kullanılarak yazarlar tarafindan hesaplanmıştır.

Leontief benzeşme analizine göre tüm sektörler değerlendirildiğinde, en düşük katsayı, 10,4747, en yüksek katsayı ise 19,5652'dir. Analiz kriterine göre katsayı ne kadar küçülürse üretimin dönemler arası daha çok benzediği varsayılmaktadır. Tablo 5'deki yer alan sektörler, en düşük ve en yüksek katsayıya sahip sektörlerin ortalamasının altında değerlere sahiptir. Bu veriler ıșığında dönemler arasında üretimde kullanılan girdi bileşenlerinin anlamlı bir şekilde farklılaşmadığı belirtilebilir. Ancak bir eşik değer bulunmadığı için Mann Whitney-U testiyle daha güvenilir sonuçlar elde edileceği düşünülmektedir. Mann Whitney-U testi sonuçlarına göre, Tablo 5'de yer alan sektörlerin üretim zincirlerinin medyanları arasında istatistiksel olarak anlamlı farklılık bulunmadığı tespit edilmiștir. Elde edilen bu sonuç daha önce ulaşılan üretim için tedarik edilen girdi bileşenlerinin farklılaşmadı̆̆ı sonucunu teyit eder niteliktedir8.

Beşinci analizde bir birim üretim sonucunda salınan $\mathrm{CO}_{2}$ miktarı ve enerji kullanım emisyonları hesaplanmaștır. Doğada bulunan bir hammeddeyi ya da insan ürünü bir yarı mâmulü işlemek, şekil vermek vb yöntemlerle îmâlât sürecine

8 Girdi-çıktı analizinin temel varsayımlarından biri teknolojinin sabit kabul edilmesidir. Bu nedenle zaman içerisinde teknoloji değişim analizi etkilemektedir. 
dâhil etmenin doğaya verdiği tahribatı en aza indirecek yöntemlerin araştırlıp geliştirilmesi günümüz dünyasının önemli gündemleri arasında yer almaktadır. Bir taraftan üretim yaparken diğer taraftan negatif dışsallıkların minimize edilerek çevrenin korunması esasına dayanan sürdürülebilir kalkınma hedeflerine ulaşlabilmesi için sektörlerin bir birim üretim sonucu çevreye yaydığı $\mathrm{CO}_{2}$ miktarının ve enerji kullanım emisyonlarının saptanması önem arz etmektedir. Beşinci analizde yapılan hesaplama ile sektörlerin çevreyi kirletme oranları belirlenmekte, yapılan durum tespiti neticesinde politika önerileri ve olası tedbirlere yönelik tavsiyeler sunulmaktadır. Analizde WIOD veri tabanında yayımlanan $\mathrm{CO}_{2}$ salınımı ve enerji kullanım emisyonu verileri kullanılmıştır (WIOD, 2019, Corsatea et al., 2019). Söz konusu veriler, ilgili sektörün toplam üretim sonucu (milyon dolar cinsinden) ortaya çıkan, enerji kullanım emisyonu miktarını göstermektedir. Enerji kullanım tablosunda, (x) sektörünün toplam üretimi sonucu açığa çıkan enerji kullanım emisyonu, girdi-çıktı tablosunda (x) sektörünün toplam çıktısını gösteren sütun toplamına bölünerek, (x) sektörünün birim başına -1 dolar- enerji kullanım emisyonları hesaplanmakta ve bu işlem tüm sektörler için tekrarlanarak sonuçlar yeni bir sütunda gösterilmektedir (Wang vd., 2019; Timmer vd., 2015). Enerji verileri ile yapılan işlemin aynısı $\mathrm{CO}_{2}$ salınımı verileriyle de yapılmaktadır (Dietzenbacher \& Los, 2000; Leontief, 1946; Leontief, 1953; Zhao vd., 2015: 917 920).

Birleşmiş Milletler Kalkınma Programı'nın (UNDP) hem büyümeyi teşvik etmek hem de negatif dışsallıkları minimize ederek sürdürülebilir doğal kaynak kullanımını tesis edebilmek için temel önerisi gelişmekte olan ülkelerin hepsinde temiz enerji sağlayacak altyapının genişletilmesi ve teknolojinin yükseltilmesidir. $\mathrm{Bu}$ çalışma çerçevesinde UNDP'nin sürdürülebilir kalkınma hedeflerinden en önemlisinin herkes için karşılanabilir, güvenilir, sürdürülebilir enerjiye erişimin sağlanması olduğu ifade edilebilir. "Erişilebilir ve Temiz Enerji" hedefi doğrultusunda, yenilenebilir enerji kaynaklarının kullanımı ile Türkiye'de emisyon azaltıcı politikaların üretilmesi önem arz etmektedir (UNDP, 2016).

Türkiye'nin 2019-2023 kalkınma hedeflerini içereb 11. Kalkınma Planının da "ulusal koşullar ölçüsünde sera gazı emisyonuna neden olan sektörlerde iklim değişikliğiyle mücadele edilmesi ve iklim değişikliğine uyuma yönelik kapasite artırımı sağlamak bu çerçevede ekonominin ve toplumun iklim risklerine dayanıklılığının artırılmasına" yönelik çevrenin korunması politika ve tedbirler öngörülmüştür (T.C. Cumhurbaşkanlığı Strateji ve Bütçe Başkanlı̆̆ı, 2019). Bu çerçevede Tablo 6'da Türkiye'deki tüm sektörlerin bir birim üretim yapması sonucunda salınan $\mathrm{CO}_{2}$ miktarı ve enerji kullanım emisyon katsayıları, büyükten küçüğe doğru sıralanarak gösterilmiștir. 
Tablo 6. Türkiye'deki Sektörlerin $\mathrm{CO}_{2}$ ve Enerji Kullanım Emisyonları

\begin{tabular}{|c|c|c|c|}
\hline SEKTÖR İSİMLERİ & $\begin{array}{c}\mathrm{CO}_{2} \\
\text { EMİSYONU }\end{array}$ & SEKTÖR İSİMLERİ & $\begin{array}{c}\text { ENERJİ } \\
\text { KULLANIM } \\
\text { EMİSYONU }\end{array}$ \\
\hline $\begin{array}{l}\text { Elektrik, gaz, buhar ve } \\
\text { iklimlendirme temini }\end{array}$ & 3,3247 & $\begin{array}{l}\text { Elektrik, gaz, buhar ve iklim- } \\
\text { lendirme temini }\end{array}$ & 53,0429 \\
\hline $\begin{array}{l}\text { Diğer metalik olmayan min- } \\
\text { eral ürünlerin imalatı }\end{array}$ & 3,2917 & Hava Taşımacılığı & 45,3031 \\
\hline Ana metal imalatı & 0,4936 & Su ulaștırma & 11,6009 \\
\hline Hava Taşımacılığı & 0,3658 & $\begin{array}{c}\text { Diğer metalik olmayan mineral } \\
\text { ürünlerin imalat }\end{array}$ & 11,2992 \\
\hline $\begin{array}{l}\text { Kok kömürü ve rafine } \\
\text { edilmiş petrol ürünleri } \\
\text { imalatı }\end{array}$ & 0,3314 & $\begin{array}{l}\text { Kok kömürü ve rafine edilm- } \\
\text { iş petrol ürünleri imalatı }\end{array}$ & 9,1063 \\
\hline $\begin{array}{l}\text { Kanalizasyon; atık toplama, } \\
\text { ișleme ve bertaraf faaliyetleri }\end{array}$ & 0,2646 & Ana metal imalatı & 9,0033 \\
\hline $\begin{array}{l}\text { Kimyasal madde ve ürün- } \\
\text { lerin imalatı }\end{array}$ & 0,1981 & $\begin{array}{l}\text { Balıkçılık ve su ürünleri yetiş- } \\
\text { tiriciliği }\end{array}$ & 6,1519 \\
\hline $\begin{array}{l}\text { Zorunlu sosyal güvenlik } \\
\text { hariç sigorta, reasürans ve } \\
\text { emeklilik fonları }\end{array}$ & 0,1858 & $\begin{array}{l}\text { Mobilya ve mobilya hariç, ahşap } \\
\text { ve mantar ürünleri imalatı; saz, } \\
\text { saman ve benzeri malzemel- } \\
\text { erden örülerek yapılan eşyaların } \\
\text { imalatı }\end{array}$ & 4,0563 \\
\hline $\begin{array}{l}\text { Finansal hizmetlere ve sig- } \\
\text { orta faaliyetlerine yardımcı } \\
\text { faaliyetler }\end{array}$ & 0,1669 & $\begin{array}{c}\text { Kauçuk ve plastik ürünlerin } \\
\text { imalatı }\end{array}$ & 3,8073 \\
\hline $\begin{array}{l}\text { Kara taşımacılığı ve boru } \\
\text { hatları ile ulașım }\end{array}$ & 0,1568 & $\begin{array}{l}\text { Kimyasal madde ve ürünler- } \\
\text { in imalatı }\end{array}$ & 3,6349 \\
\hline $\begin{array}{l}\text { İdari ve destek hizmet } \\
\text { faaliyetleri }\end{array}$ & 0,123 & Madencilik ve taş ocakçlığı & 3,6178 \\
\hline $\begin{array}{l}\text { Mobilya imalatı; diğer } \\
\text { imalatlar }\end{array}$ & 0,12 & $\begin{array}{l}\text { Bitkisel ve hayvansal üretim } \\
\text { ile avcılık ve ilgili hizmet } \\
\text { faaliyetleri }\end{array}$ & 3,2561 \\
\hline $\begin{array}{l}\text { Bitkisel ve hayvansal üretim } \\
\text { ile avcılık ve ilgili hizmet } \\
\text { faaliyetleri }\end{array}$ & 0,1182 & Ormancılık ve tomrukçuluk & 3,0338 \\
\hline $\begin{array}{l}\text { Balıkçılık ve su ürünleri } \\
\text { yetiştiriciliği }\end{array}$ & 0,1158 & $\begin{array}{c}\text { Kağıt ve kağıt ürünleri } \\
\text { imalatı }\end{array}$ & 2,9597 \\
\hline $\begin{array}{l}\text { Kağıt ve kağıt ürünleri } \\
\text { imalatı }\end{array}$ & 0,1155 & $\begin{array}{c}\text { Kanalizasyon; attk toplama, işleme } \\
\text { ve bertaraf faaliyetleri }\end{array}$ & 2,5939 \\
\hline Ormancılık ve tomrukçuluk & 0,1002 & $\begin{array}{c}\text { Diğer ulaşım araçlarının } \\
\text { imalatı }\end{array}$ & 2,3806 \\
\hline Diğer hizmet faaliyetleri & 0,091 & $\begin{array}{l}\text { Konaklama ve yemek servisi } \\
\text { faaliyetleri }\end{array}$ & 2,3519 \\
\hline Su ulaştırma & 0,0876 & Su toplama, arıtma ve temini & 2,2135 \\
\hline
\end{tabular}




\begin{tabular}{|c|c|c|c|}
\hline $\begin{array}{l}\text { Bilgisayar programla- } \\
\text { ma, danışmanlık ve ilgili } \\
\text { faaliyetler; bilgi hizmeti } \\
\text { faaliyetleri }\end{array}$ & 0,0854 & Diğer hizmet faaliyetleri & 2,1152 \\
\hline $\begin{array}{l}\text { Diğer ulaşım araçlarının } \\
\text { imalatı }\end{array}$ & 0,0796 & $\begin{array}{l}\text { Kamu yönetimi ve savunma; } \\
\text { zorunlu sosyal güvenlik }\end{array}$ & 2,0689 \\
\hline $\begin{array}{l}\text { İnsan sağlığı ve sosyal hiz- } \\
\text { met faaliyetleri }\end{array}$ & 0,0754 & $\begin{array}{l}\text { Motorlu kara taşıtlarının ve } \\
\text { motosikletlerin toptan ve per- } \\
\text { akende ticareti ve onarımı }\end{array}$ & 2,0164 \\
\hline $\begin{array}{l}\text { Gıda ürünleri, içecek ve } \\
\text { tütün ürünleri imalatı }\end{array}$ & 0,0705 & Eğitim & 1,9807 \\
\hline $\begin{array}{l}\text { Makine ve teçhizat hariç fabri- } \\
\text { kasyon metal ürünleri imalatı }\end{array}$ & 0,0617 & $\begin{array}{c}\text { İnsan sağllğı ve sosyal hizmet } \\
\text { faaliyetleri }\end{array}$ & 1,9636 \\
\hline $\begin{array}{l}\text { Mobilya ve mobilya hariç, } \\
\text { ahşap ve mantar ürünleri } \\
\text { imalatı; saz, saman ve } \\
\text { benzeri malzemelerden } \\
\text { örülerek yapılan eşyaların } \\
\text { imalatı }\end{array}$ & 0,049 & $\begin{array}{c}\text { Perakende ticaret (motorlu } \\
\text { kara taşıtları ve motosikletler } \\
\text { hariç) }\end{array}$ & 1,8746 \\
\hline $\begin{array}{l}\text { Motorlu kara taşıtlarının } \\
\text { ve motosikletlerin toptan } \\
\text { ve perakende ticareti ve } \\
\text { onarımı }\end{array}$ & 0,0488 & $\begin{array}{l}\text { Motorlu kara taşıtları ve moto- } \\
\text { sikletler hariç toptan ticaret }\end{array}$ & 1,6242 \\
\hline Eğitim & 0,0452 & $\begin{array}{c}\text { Motorlu kara taşıtları, römork ve } \\
\text { yarı römork imalatı }\end{array}$ & 1,4986 \\
\hline Gayrimenkul faaliyetleri & 0,0403 & $\begin{array}{c}\text { Tekstil, giyim eşyası ve deri } \\
\text { ürünleri imalatı }\end{array}$ & 1,2778 \\
\hline Madencilik ve taş ocakçılığı & 0,0389 & $\begin{array}{c}\text { Gıda ürünleri, içecek ve tütün } \\
\text { ürünleri imalatı }\end{array}$ & 1,2342 \\
\hline İnşaat & 0,0386 & $\begin{array}{l}\text { Kara taşımacılı̆̆ı ve boru } \\
\text { hatları ile ulaşım }\end{array}$ & 1,2147 \\
\hline Elektrikli teçhizat imalatı & 0,0369 & $\begin{array}{l}\text { Taşımacllık için depolama ve } \\
\text { destekleyici faaliyetler }\end{array}$ & 1,1322 \\
\hline $\begin{array}{l}\text { Kamu yönetimi ve savunma; } \\
\text { zorunlu sosyal güvenlik }\end{array}$ & 0,0364 & $\begin{array}{l}\text { Mobilya imalatı; diğer im- } \\
\text { alatlar }\end{array}$ & 1,107 \\
\hline $\begin{array}{l}\text { Sigorta ve emeklilik fonları } \\
\text { hariç finansal hizmet faali- } \\
\text { yetleri }\end{array}$ & 0,0351 & $\begin{array}{l}\text { Başka yerde sınıflandırılmamış } \\
\text { makine ve ekipman imalatı }\end{array}$ & 1,106 \\
\hline $\begin{array}{l}\text { Motorlu kara taşıtları ve } \\
\text { motosikletler hariç toptan } \\
\text { ticaret }\end{array}$ & 0,0329 & $\begin{array}{l}\text { Makine ve teçhizat hariç fabri- } \\
\text { kasyon metal ürünleri imalatı }\end{array}$ & 1,0844 \\
\hline $\begin{array}{l}\text { Kauçuk ve plastik ürünlerin } \\
\text { imalatı }\end{array}$ & 0,0321 & İnşaat & 1,0167 \\
\hline $\begin{array}{l}\text { Bilimsel araştırma ve } \\
\text { geliştirme }\end{array}$ & 0,0298 & $\begin{array}{l}\text { Kayıtlı medyanın basılması ve } \\
\text { çoğaltılması }\end{array}$ & 1,0125 \\
\hline $\begin{array}{l}\text { Motorlu kara taşıtları, römork } \\
\text { ve yarı römork imalatı }\end{array}$ & 0,0291 & Telekomünikasyon & 0,8403 \\
\hline
\end{tabular}




\begin{tabular}{|c|c|c|c|}
\hline $\begin{array}{l}\text { Kayıtlı medyanın basılması } \\
\text { ve çoğaltılması }\end{array}$ & 0,0285 & Elektrikli teçhizat imalatı & 0,6809 \\
\hline $\begin{array}{l}\text { Başkayerde sınıflandırılmamış } \\
\text { makine ve ekipman imalat }\end{array}$ & 0,0234 & $\begin{array}{l}\text { İdari ve destek hizmet faali- } \\
\text { yetleri }\end{array}$ & 0,6264 \\
\hline $\begin{array}{l}\text { Diğer mesleki, bilimsel ve } \\
\text { teknik faaliyetler; veteriner- } \\
\text { lik faaliyetleri }\end{array}$ & 0,023 & $\begin{array}{l}\text { Finansal hizmetlere ve sigorta } \\
\text { faaliyetlerine yardımcı faali- } \\
\text { yetler }\end{array}$ & 0,6176 \\
\hline $\begin{array}{l}\text { Konaklama ve yemek servisi } \\
\text { faaliyetleri }\end{array}$ & 0,0217 & $\begin{array}{l}\text { Zorunlu sosyal güvenlik hariç } \\
\text { sigorta, reasürans ve emeklilik } \\
\text { fonları }\end{array}$ & 0,612 \\
\hline $\begin{array}{l}\text { Bilgisayar, elektronik ve } \\
\text { optik ürünlerin imalatı }\end{array}$ & 0,0202 & $\begin{array}{l}\text { Sigorta ve emeklilik fonları } \\
\text { hariç finansal hizmet faali- } \\
\text { yetleri }\end{array}$ & 0,6083 \\
\hline $\begin{array}{l}\text { Tekstil, giyim eşyası ve } \\
\text { deri ürünleri imalatı }\end{array}$ & 0,0201 & Gayrimenkul faaliyetleri & 0,5186 \\
\hline Su toplama, arıtma ve temini & 0,012 & $\begin{array}{l}\text { Diğer mesleki, bilimsel ve } \\
\text { teknik faaliyetler; veterinerlik } \\
\text { faaliyetleri }\end{array}$ & 0,4463 \\
\hline $\begin{array}{l}\text { Perakende ticaret (motorlu } \\
\text { kara taşitları ve moto- } \\
\text { sikletler hariç) }\end{array}$ & 0,0115 & $\begin{array}{c}\text { Bilgisayar programlama, } \\
\text { danışmanlık ve ilgili faali- } \\
\text { yetler; bilgi hizmeti faaliyetleri }\end{array}$ & 0,3906 \\
\hline $\begin{array}{l}\text { Taşımacılık için depolama ve } \\
\text { destekleyici faaliyetler }\end{array}$ & 0,0106 & $\begin{array}{c}\text { Bilgisayar, elektronik ve optik } \\
\text { ürünlerin imalatı }\end{array}$ & 0,3432 \\
\hline Telekomünikasyon & 0,0101 & $\begin{array}{l}\text { Bilimsel araştırma ve } \\
\text { geliştirme }\end{array}$ & 0,3073 \\
\hline
\end{tabular}

Kaynak: WIOD 2019, 2016, Corsatea ve diğerleri, 2019 verileri kullanılarak yazarlar tarafindan oluşturulmuştur.

Türkiye için belirginleștirilmeye çalışllan ekonomik kalkınma kavşağında yer alma potansiyeli yüksek olan sektörlerden ${ }^{9}$ emisyon katsayısı en yüksek olanlar; elektrik, gaz, buhar ve iklimlendirme temini sektörü (Bloomberg, 2020)10, kok kömürü ve rafine edilmiş petrol ürünleri imalatı ve ana metal imalatı sektörleridir. Söz konusu sektörlerin üretimlerini arttırmak, kalkınmayı hızlandırken, çevrenin yüksek oranda kirlenmesine de yol açacaktır. Burada sürdürülebilir çevre ile kalkınma arasında bir ödünleşim sözkonusudur. Bu nedenle söz konusu sektörlere oluşturulan ekonomik kalkınma kavşağında yer verilmemesi tercih edilebilir, bu durumda mezkûr sektörler mevcut üretimlerimlerini arttırmadan faaliyetlerine devam etmelidir. Böyle bir durumda bile emisyon salınımının, 11. Kalkınma Planında ve Birleşmiş Milletler Kalkınma Programıda belirlenen hedeflerden uzak olduğu dikkat-i nazardan kaçırılmamalıdır.

9 Tablo 6'da koyu renkle gösterilmektedir.

10 COVID-19 salgını nedeniyle ekonomik faaliyetler azalması sonucu petrol talebi görünür bir şekilde azaldı, buna karşılık arzın paralel olarak azalmaması nedeniyle ham petrol fiyatları düştü. Düşen petrol fiyatları, petrol ürünlerine olan eğilimi arttırarak yenilenebilir enerji kaynaklarının kullanımının daha da azalmasına neden oldu. Bu durumun geçici olacağı, post-pandemi sürecinde üretimin artması ile beraber petrol fiyatlarının artacağı göz önüne alınmalıdır. 
Söz konusu hedefler ile uyumlu olarak marjinal maliyeti en düşük emisyon azaltma fırsatlarının kullanılabilmesi için aşağıda özet olarak yer veirlen politika önerileri dikkate alınabilir (T.C. Cumhurbaşkanlığı Strateji ve Bütçe Başkanlı̆̆ı, 2019).

- $\quad 2030$ 'a kadar yenilenebilir enerjinin küresel enerji kaynakları içindeki paylnın büyük ölçüde artırılmasl, enerji verimliliği ile gelişmiş ve daha temiz fosil yakıt teknolojisini kapsayan temiz enerji araştırmalarının arttırılması, enerji altyapısı ve temiz enerji teknolojisi alanlarına yatırımın teşvik edilmesi, küresel enerji verimliliği ilerleme oranının iki katına çıkarılması (UNDP, 2016),

- Yenilenebilir enerji kaynaklaryla elektrik üretiminin artırlması ve yenilenebilir enerjïle üretilen elektiriğin kullanılması,

- Doğal gaz yer altı depolama kapasitesinin artırlması,

- Karbon salınımınin azaltılmasina dair, enerji verimliliği kazanımları ve orman varliğının artırılması,

- Temiz kömür teknolojileri ile ilgili AR-GE projelerinin desteklenmesi,

- Emisyon kontrolüne yönelik; sera gazı emisyonuna sebep olan binalar ile enerji, sanayi, ulaş̧trma, atık, tarım ve ormancllı sektörlerinde, "Niyet Edilmiş Ulusal Katkı" çerçevesinde çalsşmalar yürütülmesi,

- Emisyonların kontrolünün sağlanarak hava kalitesinin iyileștirilmesi,

- $\quad$ Kirlilik ve emisyon kontrolüne yönelik mevzuatın güncellenmesi.

\section{Analiz Sonuçları}

Türkiye için ekonomik kalkınma kavşağı oluşturmak için uygulanan 5 analizden anlamlı bir sonuçlar elde edilmştir. Bu kavşakta yer alacak sektörler hem Hirschman'ın hem de Rasmussen'in kriterlerine göre anahtar sektör özelliği taşıyan sektörlerdir, bu sektörlerin ithalata bağımlılık oranları yaklaşık olarak şu şekildedir11; elektrik, gaz, buhar ve iklimlendirme temini (\%5), tekstil, giyim eșyası ve deri ürünleri imalatı (\%13), kağıt ve kağıt ürünleri imalatı (\%19), kok kömürü ve rafine edilmiş petrol ürünleri imalatı (\%21), kimyasal madde ve ürünlerin imalatı (\%28), bilgisayar, elektronik ve optik ürünlerin imalatı (\%35), ana metal imalatı (\%36). Geri bağlantı etkisi incelendiğinde, bu sektörlerin en çok kendi sektörlerinden ithal ara girdi temin ettiği sonucuna ulaşlmıştır. Ekonomik kalkınma kavşağında yer alma potansiyeline sahip olan sektörler, bir taraftan bağlantı etkilerinin kuvvetli olması nedeniyle ekonomiyi harekete geçirirken, diğer taraftan ithal girdi kullandıkları için dışa bağımlılı̆̆ daha fazla arttıracaktır. Pandemi, ticaret savaşı, iç-dış savaş, doğal afetler vb. sebeplerle uluslarası tedarik zincirinin aksadığı dönemlerde pek çok sektör de bu aksamadan olumsuz etkilenebilmekte ve üretimlerinde aksamalar meydana gelebilmektedir. Bu etkileri

11 Tek istisna, tekstil, giyim eşyası ve deri ürünleri imalatı sektörüne aittir. İstisnî olmasındaki temel neden, salgin süresince ülkemiz bașta olmak üzere ABD ve pek çok Avrupa ülkesinin, maske, tıbbi koruyucu kyyafet ihtiyacını sağlayan güçlü ve esnek üretim yapısına sahip olmasıdır. 
en aza indirebilmek amacıyla yerli ve milli imkânlarla ara girdi üretimine ağırlık verilmesi gündeme getirilebilir.

Söz konusu sektörlerin, dönemler arasında girdi katsayılarında önemli bir değişim olup olmadığını belirlemek amacıyla uygulanan Leontief benzeşme analizi ve Mann Whitney-U testi sonuçlarına göre girdi bileșenlerinin anlamlı bir şekilde farklılaşmadığı, sağlam bir üretim altyapısına sahip olduğu sonucuna ulaşılmıştır.

Bu çalışmada özenle incelenmeye değer bir diğer analiz sonucu ise sektörlerin bir birim üretim sonucu çevreye yaydığı $\mathrm{CO}_{2}$ salınımı ve enerji kullanım emisyonlarıdır. Özellikle elektrik, gaz, buhar ve iklimlendirme temini sektörü başta olmak üzere kok kömürü ve rafine edilmiş petrol ürünleri imalatı sektörü ve ana metal imalata sektörünün, hem $\mathrm{CO}_{2}$ salınımı hem de enerji kullanım emisyon katsayıları çok yüksek düzeydedir. Söz konusu sektörler 11. Kalkınma Planı ve UNDP’nin sürdürülebilir kalkınma için belirlediği hedeflerin uzağında $\mathrm{CO}_{2}$ ve enerji kullanım emisyonlarına sahiptir. Bu sektörlerin emisyonlarının düşürülmesi için gerekli adımların atılması ve emisyon miktarları düşürülünceye kadar kalkınma kavşağında yer almaması tavsiye edilebilir.

Bu yorumlar neticesinde post-pandemi süreci için oluşturulan ekonomik kalkınma kavşağı önerisi Şekil 1'de gösterilmektedir.

Şekil 1. Pandemi Sonrası Dönemde Türkiye için Ekonomik Kalkınma Kavşağı

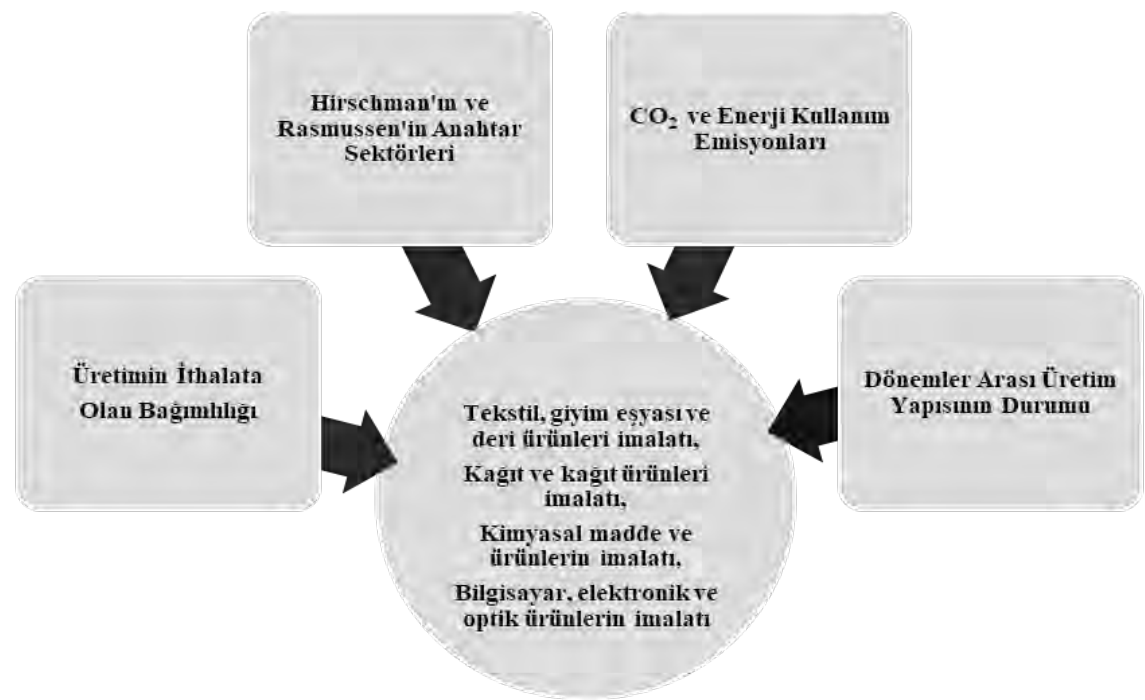

Kaynak: Yazarlar tarafindan oluşturulmuştur. 


\section{Sonuç}

COVID-19 pandemisinin ekonomik alanda sebep olduğu yıkıcı etkilerini azaltmanın yollarından biri de ekonomik kalkınmayı hızlandıracak politakalar uygulamakdır, üretimin arttırılması bu noktada önemli bir araç olarak değerlendirilmeldir. Pandemi sürecinde küresel tedarik zincirinde ortaya çıan aksamalar ithal ara giridi bağımlılı̆̆ az bir îmâlât yapısı oluşturmanın önemini bir kez daha gösterdi. Post-pandemi sürecinde Türkiye'nin hangi sektörlere odaklanılması gerektiğini tespit edebilmek amacıyla, Giddens'in pozitivizm ve hermeneutik görüş arasında oluşturduğu kavşak yaklaşımından esinlenerek yeni bir kalkınma modeli önerilmektedir. Çalışma girdi-çıktı analizi çerçevesinde şekillendirilmiş, kullanılan veriler ve elde edilen sonuçlar durum tespiti için anlamlı doneler sağlamıştır. Bu çerçevede oluşturduğumuz ekonomik kalkınma kavşağı, sadece anın fotoğrafını çekmekte olup post-pandemi süreci için geliştirilecek politikalarda dikkat edilirse faydalı olabilecek belirli noktalara işaret etmektedir.

Ekonomik kalkınma kavşağı oluşturulurken göz önünde bulundurulan kriterlerden birincisi kavşakta yer alacak sektörlerin hem Hirschman hem de Rasmussen kriterlerine göre anahtar sektör özelliklerini taşımasıdır. İkinci kriter düşük ithal girdi bağımlılığıdır. Üçüncü kriter, üretiminde kullanılan girdi bileșenlerinde dönemler arası farklılıkların olmamasıdır. Dördüncü kriter ise îmâlât neticesinde çevreye yayılan $\mathrm{CO}_{2}$ ve enerji kullanım emisyonlarının düşük olmasıdır.

Bu kriterler yardımıyla oluşturulan ekonomik kalkınma kavşağında yer alan sektörler; tekstil, giyim eşyası ve deri ürünleri imalatı, kâğıt ve kâğıt ürünleri imalatı, kimyasal madde ve ürünlerin imalatı, bilgisayar, elektronik ve optik ürünlerin imalatı sektörleridir. Bu sektörler, aynı zamanda, COVID-19 salgınıyla mücadele için maske, tıbbi koruyucu kıyafet, dezenfektan, hastaneler için özel üretilen kullan-at çarşaf, havlu vb. gibi malzemelerin üretimini gerçekleştiren ve solunum cihazı üretiminde aktif rol alan sektörlerdir.

Pandeminin ekonomik tahribatını en aza indirmek, Türkiye'nin sürdürülebilir kalkınma hedeflerine katkı sunmak ve kalkınmanın sürdürülemez çevreye neden olmasını önlemek bu çalışmanın temel motivasyonları arasındadır. Bu motivasyonla, yukarıdaki bölümlerde bahsi geçen tavsiyelerin/önlemlerin dikkate alınmasının önemine bir kez daha vurgu yapmak faydalı olabilir. Elektrik, gaz, buhar ve iklimlendirme temini sektörü başta olmak üzere kok kömürü ve rafine edilmiş petrol ürünleri imalatı sektörü ve ana metal imalat sektörlerinin $\mathrm{CO}_{2}$ salınımı ve enerji kullanım emisyonları azaltılması kaydıyla ekonomik kalkınma kavşağında yer verilmesi, tesviye edilen kavşağın ekonomi üzerindeki pozitif etkilerini arttıracaktır. Ayrıca, ekonomik kalkınma kavşağında yer alması önerilen sektörlerin, ivedilikle ithal girdi bağımlılığının daha da azaltılması, yerli ve milli imkânlarla îmâlâtlarını gerçekleştirilmesi için gerekli adımların atılması çalışmanın tavsiyeleri arasında yer almaktadır. 
Tüm bu şartların gerçekleşmesi sonucu, bir kavşakta toplanacak sektörler, ekonomik kalkınmanın anahtarı olacaktır.

Post-pandemi sürecinde tavsiye edilen kalkınma kavşağının etkinliğini arttırmak için aşağıda yer allan ek önmelere de başvurulabilir; Kavşakta yer verilen sektörlerin üretimlerini arttırmaya yönelik hibe, finansman ve vergi teşvikleri geliştirilmeli. Küresel talepte oraya çıkan daralma göz önünde bulundurularak, arz fazlası olan ürünlerde devlet nihai alıcı olmalı, iç talebin canlandırılması için KDV ve ÖTV oranlarını düşürülmelidir. Küresel tedarik zincirindeki aksamalardan en az düzeyde etkilenmek için yerli ara girdi tedariğine ağırlık verilmelidir.

\section{Kaynakça}

Akande, B. O. O. (1995). Hirschman's Unbalanced Strategy: A Study of Linkage Effects in A Developing Economy: The Case of Nigeria, The University Op Oklahoma Graduate College. Doktora Tezi.

Alejandro, C. M. \& Sancho, F. (2006). Missing Links in Key Sector Analysis. Economic Systems Research, 18(3), 319-325. DOI: 10.1080/095353106008444409.

Altan, Ş. (1996). Girdi-Çıktı Analizinde Girdi Katsayılarııın Tahmininde Değişik Bir Yöntem ve Uygulaması. Doktora Gazi Üniversitesi, Sosyal Bilimler Enstitüsü, Yayımlanmamış Doktora Tezi.

Bezdek, R. H. (1984). Tests of Three Hypotheses Relating to the Leontief Input-Output Model. Royal Statistics Society, 147(3), 499-509. DOI: 10.2307/2981581.

Bloomberg, (2020). En güncel brent petrol fiyatlarl: https://www.bloomberght.com/ emtia/brent-petrol [ET: 01.05.2020].

Chenery, H. B. \& Watanabe, T. (1958). Tsunehiko: "International Comparison of the Structure of Production". Econometrica, 26(4), 487-521.

Corsatea, T. D., Lindner, S., Arto, I., Roman, M. V., Rueda-Cantuche, J. M., Afonso, A. V. \& Neuwahl, F. (2019). World Input-Output Database Environmental Accounts (No. JRC116234). Joint Research Centre (Seville site).

Cuello, F. A., Mansouri, F. \& Hewings, G. J. (1992). The İdentification of Structure at the Sectoral Level: A Reformulation of The Hirschman-Rasmussen Key Sector İndices. Economic Systems Research, 4(4), 285-296. DOI: 10.1080/09535319200000027.

Demir, İ. (2020). Kovid-19 Salginın Seyri ve Türkiye Ekonomisi. Demir İ. (Ed.) Kovid-19 (Koronavirüs) Salgınının Ekonomik Etkileri içinde (Bölüm 1:7-16). Ankara.

Dietzenbacher, E. \& Los, B. (2000). Structural Decomposition Analyses With Dependent Determinants. Economic Systems Research, 12(4), 497-514. DOI: 10.1080/09535310020003793.

Dünya Çevre ve Kalkınma Komisyonu, (1987). Ortak geleceğimiz, (B. Çorakçı, Çev.) Ankara: Türkiye Çevre Sorunları Vakfı Yayınları.

Gamgam, H. \& Altunkaynak, B. (2012). Parametrik Olmayan Yöntemler. 4. Baskı. Ankara: Seçkin Yayıncılık. 
Genty, A., Arto, I. \& Neuwahl, F. (2012). Final Database Of Environmental Satellite Accounts: Technical Report On Their Compilation. WIOD deliverable: http://www. wiod.org/publications/source_docs/Environmental_Sources.pdf [02.05.2020]

Giddens, A. (2002). Retorik Hermeneutik ve Sosyal Bilimler. (H. Arslan, Çev.) (s.20-39), İstanbul: Paradigma Yayınları.

Güler, İ. (2019). İktisadi Kalkınma Temelinde Gayrimenkul Ekonomisi. Ankara: Gazi Kitabevi.

Han, E. \& Kaya, A. A. (2012). Kalkınma Ekonomisi: Teori ve Politika. Ankara: Nobel Yayın Dağıtım.

Hazari, B. R. (1970). Empirical Identification of Key Sectors in the Indian Economy. The Review of Economics and Statistics, 52(3), 301-305. DOI: 10.2307/1926298.

Hirschman, A. O. (1978). The Strategy of Economic Development. (Ilk basımı New Haven, CT, Yale University Press, 1958 kaynağına ulaşılamamıştır) New Haven: Yale University Press.

Işık, E. \& Serim, H. (2017). İktisadı Hermeneutikle Anlamak. Bilgi Dergisi, 19(2), 67-90.

Korum, U. (1963). Input-Output Analizi. Ankara Üniversitesi Siyasal Bilgiler Fakültesi Yayınları, Yayın No. 164-146, Ankara: Sevinç Matbaası.

Küçükkiremitçi, O. \& Güler, İ. (2020). Ticaret Savaşları Ekseninde Türkiye'de Üretimin Ithalata Bağımlılık Düzeyinin Dönemler Arası Benzerlik Analizi. M. Çetinkaya ve G. Muratoğlu (Ed.) Ticaret ve Kur Savaşları-Küresel Ekonomik Politiğe Yansımaları Küresel Ekonomik Politiğe Yansımaları içinde (Bölüm 4: 119-156). Ankara: Gazi Kitabevi.

Küçükkiremitçi, O. (2011). Türkiye Sanayi Strateji Belgesi Temelinde İmalat Sanayinin Yapısal Analizi. Memleket Siyaset Yönetim Dergisi, 15, 53-94.

Küçükkiremitçi, O., Karaca, M. E. \& Eşiyok, B. A. (2010). Türkiye'nin İhracatında Öne Çıkan Sektörlerde Temel Pazar Ülkeler, Rakipler ve Rekabet Gücü. Türkiye Kalkınma Bankası AŞ, 1-42.

Leontief, W. (1936). Quantative Input and Output Relations in the Economic System of the United States. The Review of Economic Statistics, 18(3), 105-125. DOI: $10.2307 / 1927837$.

Leontief, W. (1946). Exports, İmports, Domestic Output, and Employment. The Quarterly Journal of Economics, 171-193. DOI: 10.2307/1880684.

Leontief, W. (1949). Structural Matrices of National Economies. Econometrica: Journal of the Econometric Society, 273-282. DOI: 10.2307/1907314.

Leontief, W. (1951). The Structure of the American Economy, New York: Oxford University Press.

Leontief, W. (1953). Domestic Production and Foreign Trade: The American Capital Position Reexamined. Input-Output Economics (1986) kitabı içinde, (2nd Edition), (s.241-260). New York: Oxford University Press. 
Leontief, W. (1970). Environmental Repercussions and the Economic Structure: An Input-Output Approach. The Review of Economics and Statistics, 262-271. DOI: $10.2307 / 1926294$.

Leontief, W. (1985). Input-Output Analysis, Input-Output Economics (1986) kitabı içinde, (2nd Edition), (s.19-40). New York: Oxford University Press.

Quesnay, F. (1758). Tableau Economique. In: Kuczynski, M. and Meek, R. L. (Editor), Quesnay's Tableau Economique. Macmillan, London.

Rasmussen, P.N. (1956). Studies in Intersectorel Relations. Amsterdam: Nourth-Holland.

Reyes, F. A. (1996). Important Coefficients and Structural Change: A Multi-Layer Approach. Economic Systems Research, 8(3), 235-246. DOI: 10.1080/09535319600000017.

Reyes, F. A. (2002). Structural Transformations and Important Coefficients in the North American Economies. Economic Systems Research, 14(3), 257-273. DOI: 10.1080/0953531022000002503

Ricardo, D. (1891). Principles of Political Economy and Taxation. G. Bell and Sons.

Sonis, M., Hewings, J. D. \& Guo, J. (2000). A New İmage of Classical Key Sector Analysis: Minimum Information Decomposition of the Leontief İnverse. Economic Systems Research, 12(3), 401-423. DOI: 10.1080/09535310050120952.

T.C. Cumhurbaşkanlığı Strateji ve Bütçe Başkanlığı, (2019). On Birinci Kalkınma Planı 2019-2023, Ankara.

Timmer, M.P., Dietzenbacher, E., Los, B., Stehrer, R. \& De Vries, G.J. (2015). An İllustrated User Guide to the World Input-Output Database: The Case of Global Automotive Production. Review of International Economics, 23(3), 575-605. DOI: 10.1111/ roie. 12178.

Türkiye İktisadi Girișim ve İş Ahlakı Derneği (İGİAD) (2020). Salgın Sonrası Kobilerin ve İstihdamın Korunması Íçin Alınması Gereken Tedbirler: https://igiad.org.tr/igiad-covid19-ekonomik-rapor, (ET: 09.05.2020).

Türkiye İstatistik Kurumu (2020). Elektrik Tüketim İstatistikleri: http://www.tuik.gov. tr/PreTablo.do?alt_id=1029, YOK [ET: 13.05.2020].

Ulutaş, U. (2020). Koronavirüs Sonrası Küresel Trendler. Ulutaş U. (Ed.) COVID-19 Sonrası Küresel Sistem: Eski Sorunlar Yeni Trendler içinde (Bölüm 1: 10-19). Ankara: SAM Yayınları.

UNDP (2016). Sürdürülebilir Kalkınma için Küresel Amaçlar: Amaç 7. Erişilebilir ve Temiz Enerji: https://www.kureselamaclar.org/amaclar/erisilebilir-ve-temiz-enerji/ [ET: 22.04.2020].

Viet, V. Q. (1980). Sensitivity Analysis In Input-Output: Theory and Application. New York Üniversitesi. Doktora Tezi.

Walras, L. (1954). Elements of Pure Economics, or the Theory of Social Wealth. Çev. W. Jaffé, Homewood, Ill.: R.D. Irwin. (Eserin orijinali 1874'te yayımlandı).

Wang, Y., Li, J., Lee, L.C., Wang, M. \& Du, H. (2019). A Review of Input-Output Model Application Hot Spots in the Energy and Environment Fields Based on Co-Words 
Network Analysis. Environmental Reviews, 27(4), 567-574. DOI: 10.1139/er-20180110.

WIOD-World Input-Output Database (2019). Economic, environmental and social effects of globalisation: WIOD Environmental Accounts-2019: https://ec.europa. $\mathrm{eu} / \mathrm{jrc} / \mathrm{en} / \mathrm{research}$-topic/economic-environmental-and-social-effects-of-globalisation, [ET: 05.01.2020].

WIOD-World Input-Output Database, (2016). National Input-Output Tables, Turkey, NIOT: http://www.wiod.org/database/niots16 [ET: 26.03.2020]

Zhao, Y., Zhang, Z., Wang, S., Zhang, Y. \& Liu, Y. (2015). Linkage Analysis of Sectoral CO2 Emissions Based on the Hypothetical Extraction Method in South Africa. Journal of Cleaner Production, 103, 916-924. DOI: 10.1016/j.jclepro.2014.10.061. 